


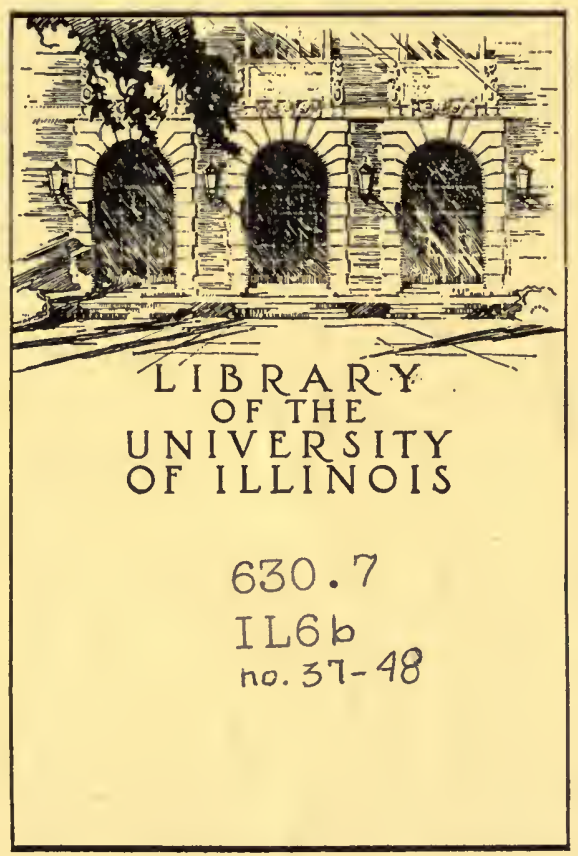

Agric.

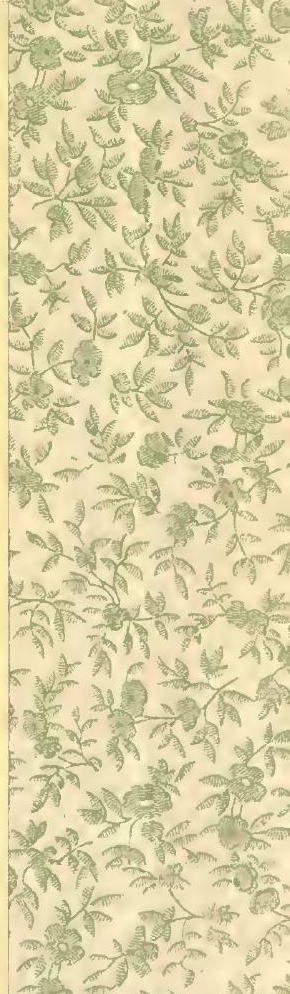




\section{NON CIRCULATING}

\section{CHECK FOR UNBOUND}

NREUIATING COPY

\section{NON CIRCULATING}

\section{OHECK FOR UNBOUND}

CIRCULATING COPY 





\section{UNIVERSITY OF ILLINOIS,}

\section{Agricultural Experiment Station.}

URBANA, JULY, 1896.

\section{BULLETIN NO. 45 .}

\section{VARIETIES OF APPLES.}

The APPle ORChARD.

The Trustees of the University of Illinois early expressed their belief in the value of experimental work in agriculture, and one of the farms which came into their possession was almost from the first known as the "Experimental Farm."

From the Trustees'Report for I869, p.46, the following is quoted:

In regard to the orchard proper, the most important feature that we now recommend, is the procuring and planting of samples of all the improved varieties of fruits for identification and comparison,- - a sort of fruit tree museum of varieties that will be at all times accessible for reference.

With this thought in mind a great many varieties of apples and other fruits were obtained and planted,-how many will never be known. In the Trustees' Report for I870, p. 44, Dr. J. M. Gregory says, under date of March 8 th, that there were plinted the last spring in the apple orchard 2,193 trees of about 1,200 varieties, and about 600 trees were set in the nursery till the drainage of some wet places would permit them to be planted in the orchard.

In this same report, p. 63, Mr. H. K. Vickroy, who held the position of orchardist, says :

The trees of this orchard were purchased of A. M. Lawver, South Pass [now Cobden], Ill., the fall of 1868 and heeled on the University grounds until the following spring. Roots were badly infested with * Pemphigus pyri, Fitch, causing knotty excresences on the roots, commonly, but incorrectly, called in Illinois the "Woolly Aphis." In the spring before planting in the orchard we washed the roots clean and immersed them in strong lye and heeled in again until the ground was prepared to receive them. The

*Schezoneura laingera (Hansen), apple-root plant-louse. 
groun 1 was deeply plowed and thrown in ridges, upon which the trees were set about the same depth they stood in the nursery, in quincunx order, ${ }^{*} 24$ feet each way, every tenth row being left for a row of evergreens. *** Planted 2, I93 trees, about I,000 known varieties. *** We planted in nursery about 600 apple trees, one to three years old, for the purpose of filling in wet places in the orchard when drained, and replacing any that might die.

On page 76 the Standing Committee on Horticulture of the Board of Trustees reported:

Of the 3,000 apple trees obtained from A. M. Lawver, supposed to embrace about I,5CO varieties, 2,180 were planted permanently in orchard, and the remainder set in nursery, to be planted the present season.

In the report for $187 \mathrm{I}$, p. 67 , Dr. Gregory says that the apple orchard now contains 2,3I9 trees, embracing about I, I8o varieties, and on p. 93 Dr. Burrill says that the orchard has certainly done well.

In the report for 1872 , p. 96 , Dr. Burrill states that Cooper's early white, Rambo, and a seedling of the red Siberian crab, have each borne fruit. In the same connection there is given a list of the varieties of apples in the orchard at that time. This list contains 993 names.

In the sixth report, 1873, p. 91 , the following statements are made by Dr. Burrill:

There were eighty-nine varieties bore from one apple to one-half peck each; but quite a number of them, where there were only one or two specimens on a tree, dropped off before maturity, and some were stolen, so we could not tell whether they were true to name or not. We found several instances where they were labeled with different names, proving to be the same thing. About two-thircls of what bore were summer fruit. We found nothing worthy of special mention, without it is a seedling of the Siberian crab, which has borne fruit for the past three seasons. The fruit is as large as the Transcendent, and of fine quality, and an abundant bearer.

Almost all the trees have made a good growth. Several varieties have died.

We still find occasionally the apple-root plant-louse above and below the surface of the ground.

In the seventh report, 1874, p. 25 , is found this phrase: "An apple orchard of 1,200 varieties is beginning to bear," and on page 90 Dr. Gregory, in his report to the Trustees, says: "The reports of Mr. Vickroy on the orchards, the small fruit plantations, and the forest plantations are full of valuable facts and suggestions." This report was not published and there is no further mention of it. The manuscript has not been preserved.

In the eighth report, p. I40, Dr. Burrill says:

I submit the following as the report for the Department of Horticulture for the six months ending September I, I 875 :

Agreeable to instructions of the Board of Trustees, the south half of the apple orchard has been replowed, so as to level the ground formerly thrown into ridges. The trees have undoubtedly suffered some by so doing, but the wet season has been very

*The trees were really planted 20 feet apart instead of 24 as reported. 
favorable for them. Quite a number of trees from the low and wet places were taken up and those seemingly worth it were transplanted in the old rows where trees were missing.

This transplanting from the low ground to that better drained was undoubtedly done at the time indicated, but no further record of it has been preserved, so that there is no means of knowing just what trees were taken up and reset, or where they were planted. In several cases in the record trees are reported dead, and without any explanation or notice of replanting the record goes on giving dates of leafing, blooming, and fruiting. No doubt some of the trees spoken of as having been transplanted in 1875 were put in these places.

In this same volume, p. 199, Dr. Burrill says in his report for September, 1876 :

The apple orchard has attracted considerable attention during the summer from the number of trees in fruit. Most of the trees upon the dry ground are in fine condition, having recovered from the severe trial of the winter of $1872-3$. Those planted on low, wet ground have usually died or are now diseased and worthless. The north side of the east and west road appears better than the south side, owing, it is thought, to the difference in treatment. Previous to the spring of 1873 the cultivation for both was the same, but at this date clover was sown upon the north side and corn grown again upon the south. The following spring (1874) clover was sown upon all not previously seeded, but the stand being poor the land was again plowed in 1875 and corn planted. So for 1876 , objections having been made to the ridges upon which the trees were planted, the earth was thrown by the plow away from them, and the two summers proving wet the trees suffered. More of these have been injured by the wind than elsewhere, the roots having little hold upon the ground.

So far as examinations have been made most of those fruiting prove true to name. Some kinds not generally cultivated in the vicinity give promise of much value, but the most of those unknown to fruit growers seem to be unworthy of extensive planting. Quite a number of kinds show twig blight this season, and many of the apples are scabby from a fungus. But these troubles may not occur during drier summers. Records of the earlier varieties have not been fully kept this year from, in part, the centennial visits and from the pilfering of visitors to the orchard. *** On September 8 th there were 340 trees in fruit, embracing about 300 varieties.

The next published account of the orchard is found in the tenth report, and is for the season of 1878 . In it Dr. Burrill says:

Very little fruit was obtained from the apple orchard, and but few specimens from the small amount produced were perfectly sound. Other orchards in the vicinity, with rare exceptions, did but little if any better, but many others do present a better appearance in the uniformity and healthfulness of the trees. It cannot be expected that a thousand varieties of untried fruits will succeed so well as a few chosen kinds; yet people forget this fact when comparing this experimental orchard with others. The land is, in many places, too wet for apples, and the trees suffer accordingly. Some are plainly injured by the exposure of their roots in plowing.

The orchard can never become a profitable one in the ordinary sense; yet the great $v$ alue of even one $v$ ariety of fruit, better for the locality than any usually planted, should such a one be found, warrants the continuance of the trial. But the trees are now so large that a limited number of cattle and hogs pasturing among them would scarcely do any damage. There are evergreens which might be molested, and the planting of young trees to fill up spaces would be prevented, but, on the whole, it is here 
recommended that a fence be put across the east side, and the land prepared for pasturage.

In December, I879, Dr. Burrill made the following statement (see tenth report, p. 209):

A summary of the record of the Experimental Apple Orchard is presented here, believing it to be of interest.

Fruit was gathered, and a record made of four hundred and seven (407) varieties. A few of the earliest kinds were missed, owing to the pressure of other labors and the propensity of visitors, etc., to help themselves.

Taken together, the apples were smoother and better than they have been in any preceding year. Though the quantity upon each tree was usually small, the total amount was greater than heretofore in any one year. The trees, too, with one exception, to be hereafter noticed, are apparently in better condition than for several years back.

Whether any one kind not usually cultivated will prove better than those commonly grown in the vicinity cannot yet be determined; but this year's fruiting gave much more promise than heretofore of several valuable new kinds. ***

Taking the whole orchard together, the following percentages are made from the fruiting trees, the size of the trees being considered:

Bearing only a few apples, 82 per cent.

Bearing an average crop, 12 per cent.

Bearing a large crop, 6 per cent.

Ripening in October or earlier, 29 per cent.

Ripening later than November I, 7 I per cent.

Following the winter of $1876-7$, quite a number of trees died or showed signs of severe injury, and the same difficulty has shown itself to a less extent this season. In the country at large, it appears this trouble is much more prevalent than has ever heretofore been reported, and, from my investigations, proves to be the same as witnessed now and previously in the University orchard. Apple trees are subject to very many diseases, and injuries and death or unhealthiness results from many causes, requiring careful examination and accurate knowledge to determine. In this case the in jury is confined to the trunk above the surface of the ground, usually extending upward not more than one foot, but sometimes reaching and even extending over the larger branches. It is not confined to any side, but occurs more often on the southwest. In early spring, little or no evidence is apparent of injury. The tree puts forth its leaves as usual, and the setting of fruit is not interfered with. But. by the middle of summer the whole tree looks sickly, and often dies with its leaves and fruit attached or not.

The bark of the injured portion is separated from the wood and dies. Sometimes a new bark is formed beneath, and the tree survives. If the part thus affected is not large, little damage is done, and the wound may become entirely covered by a new growth.

The cause is the freezing of the trunk when in peculiar conditions as to the abundance and fluidity of the sap. The injury is thus a mechanical one, and is attended with precisely the same phenomena as when such a wound is made by man. We have noticed that trees of the same variety are usually similarly affected. In the country at large it is the Rawle's Janet this year of which there is the most complaint, yet this has usually been considered hardy. So some of the new kinds in the University orchard thus injured need not be discarded on this account. 


\section{PESTS.}

As has been already stated, the roots of the trees received were badly infested with the apple-root plant-louse and the roots were washed and then immersed in strong lye, the object being to destroy the louse. The remedy used was apparently not effective, because Dr. Burrill says in his report for 1872 : "We still find occasionally the apple-root plant-louse." Since then the louse has increased greatly in numbers so that none of the trees seem to have been free from them for at least ten years, and in many cases all the surface roots, to a depth of 8 to 10 inches, have been badly infested; so badly in some cases that that alone might be taken as a sufficient reason for the trees bearing no better.

The oyster shell bark-louse was at one time very abundant; but that has now almost disappeared and the scurfy bark-louse has taken its place, and on some trees is very abundant. The apple leaf hopper has often been in sufficient numbers to cause considerable injury. Of leaf eating insects the most constantly troublesome has been the apple leaf crumpler. Others have done more or less damage occasionally but none of them seem to have persisted through a series of years. Except for the year 1888, the coddling moth seems to have been a serious pest all the time.

\section{Soll Treatment.}

Previous to the fall of 1888 , the whole orchard had been seeded to clover. That fall it was recommended that the orchard be fenced in and the land prepared for pasture. This was done, and the land was pastured or mowed until I888. The clover was soon driven out by Kentucky blue grass, so that when the present Experiment Station management came into possession there was a close blue grass sod over the whole orchard. In the spring of I888, nearly one-half the orchard was put in cultivation and has been kept so since. The remainder is still in blue grass sod.

\section{IDENTITY OF VARIETIES.}

It is not known just how many varieties of apples were planted.* In one place it is stated that the trees obtained of $\mathrm{Mr}$. Lawver were supposed to embrace about I,500 varieties. In another place it is stated that about 1,200 varieties had been already planted. The number is given in another place as about I, I80, in another place I,000. At another time the published list

*The orchard record at present contains I,264 names, but of these, some at least seem never to have been planted. Some are given as having been planted in rows of which there is no further record and of which no one has any recollection. Some of these latter varieties have been found growing in scattered parts of the orchard where they were supposed to have been planted for something else. 
of varieties actually planted contained 993 names. While the greater part of the varieties planted were obtained from $\mathrm{Mr}$. Lawver, many were received from other sources.

Dr. Burrill says in 1876 that so far as examinations have been made, most of the varieties fruiting prove true to name; but in his report for 1879 he says there are 44 varieties, out of a total of 407 that are said to have fruited, which were considered to be not true to name. From later and more careful study it is believed that 10 per cent. is a low estimate of the proportionate number of varieties not true to name. At least one of the sources of error in naming is to be found in taking up trees from one place and planting in another without the proper change having been made in the record. From the general character of some of the trees and fruit it would seem that some of the cions had failed to grow, and that the roots on which they were grafted had grown and been set out for the varieties. There were several cases in which the fruit borne was so inferior as to be unworthy of attention at any place. There seems to be scarcely any room to doubt that the varieties as received from some of the sources were more or less mixed.

But the question of identity is a difficult one to decide, except on intimate personal acquaintance with the variety. There are individual characters which it is impossible to describe accurately or minutely, but which nevertheless distinguish the variety. These are seldom all present in the same specimen. In fact, it is not uncommon to find a number of specimens together, all of which lack some one very characteristic mark. As a rule, the more minute the description given of a variety, the more likely it is to fall into error. This comes from individual variation, - there are not two apples exactly alike, from variation with the season,apples grown on the same tree are not the same in their minor characteristics year after year; and from soil peculiarities, climatic, or other differences,- - apples grown in one locality are different in form, quality, or other characters from those grown in another. Apples grown on one tree are different from those grown on another.

Descriptions which we have made of the same variety in different seasons have varied more or less. Sometimes enough difference is found between descriptions to justify one in thinking they were made for different varieties. In more than one instance varieties as planted have been considered at one time true to name, and at another not true. There may be two or three reasons for this. The judgment of one person may not agree with the judgment of another as to the amount of variation from the published description which is to be allowed, and the judgment of 
the same person is apt to change as a more mature study of varieties is made. The fruits of the same variety. do vary one year with an another, so that fruit which may seem to agree very well one year with descriptions as published, will not another. Fruit which is undoubtedly of the same variety is not always the same on different trees. Summer pruned royal on one tree has been constantly larger than on another which has been grown under similar conditions, and at the same time the tree bearing the largest fruit has been also the more productive. Jefferies on different trees has varied considerably. One tree has been much larger than the other and has borne fuller crops but of smaller. fruit. Other instances could be given. Whether this is from a soil difference, bud variation, or from the effect of the root on which the variety was put need not here be considered. There is reason to believe that all these things have their influence.

There may have been a difference in the authorities consulted. Among the three writers who are commonly recognized in this country as standard authority, Downing, Warder, and Thomas, it is not uncommon to find descriptions of a variety which seems almost contradictory, as when one says "flesh, white" and another says "flesh, yellowish." (See fall pippin, Downing and Thomas.)

To illustrate further, the following descriptions of Gravenstein are taken from Downing, Warder, and Thomas and another is given as made of the fruit itself grown here.

Gravenstein (Downing).-A superb looking German apple. *** Fruit, large, rather flattened, and a little one-sided or angular, broadest at the base. Stalk, quite short and strong, deeply set. Calyx, large, closed, in a wide, deep, rather irregular basin. Segments, long, irregular, recurved. Skin, greenish yellow at first, but becoming bright yellow, and beautifully dashed, penciled, and marbled with light and deep red and orange. Flesh, tender and crisp, with a high flavored, somewhat aromatic taste. Very good. September and October. A valuable apple for market or cooking, succeeding admirably wherever grown.

Gravenstein (Warder).-Fruit, large, globular-oblate, angular. Surface, smooth, yellow, partially covered with mixed and splashed scarlet; dots, rare. Basin, medium, regular. Eye, small, closed. Cavity, deep, regular. Stem, short. Core, regular, globular, or pointed toward the eye, closed, clasping. Seeds, smail, pointed. Flesh, yellow, fine grained, breaking, juicy. Flavor, subacid, aromatic. Quality, best. Table and kitchen. Season, August and September.

GRAVENSTEIn (Thomas),-Rather large, roundish, slightly oblate, obtusely ana obscurely ribbed. Surface, a little wavy, striped and splashed with bright red on a yellow ground. Stalk, three-quarters of an inch long. Cavity, rather deep. - Calyx, large. Basin, deep, narrow. Flesh, tender, juicy, very rich, subacid or rather acid. high flavored. Mid-autumn. Productive, handsome, and excellent. Fine in all localities.

Gravenstein (Specimens grown on the Experiment Station Farm).-Fruit, medium size, oblate, more or less ribbed, sometımes oblique. Color, pale, waxen, yellow 
marbled with light red and splashed and striped with a darker but still light, clear red, running into lines about the cavity; dots, small, light, inconspicuous. Cavity, rather large, open, with more or less russet. Stem, medium to long, stout, straight. Basin, rather broad, wavy, Calyx, small, open. Core, small, rather broad. Seeds, very small, short, and plump. Flesh, cream color, very tender, breaking, juicy, moderately rich, very pleasant, subacid. Very good in quality. Season, October. Dessert and kitchen. The tree is a rather large, fairly regular grower, upright, spreading, but a rather shy bearer. While the fruit is handsome, it is too small to be a good market apple.

\section{LIFE OF THE TREES.}

The trees in this orchard have been dying more or less from the time of planting. It is usually expected that some trees will die soon after being planted, but the loss of newly set trees in this case was very small. Trees planted in undrained or poorly drained land continued to die for several years until all were either dead or had been moved to other places. Most of them died.

According to the report published for 1879 the winter of $1876-7$ was very severe on apple orchards generally. Many of the trees in the experiment orchard which had been in apparently good health up to this time either died or were found to be in an unhealthy condition. A part of these unhealthy trees soon died, others followed later, and a part recovered.

Again, following the winter of $1884-5$, many trees were found to be in a very unhealthy condition, and many trees died within one or two years. The winter of $1884-5$ was very severe, and following it many whole orchards of the central northwest either died or were found to be so badly injured as to be worthless for further fruit production. In the general mind this is known as winter killing. Perhaps it would be better not to attribute everything to the severity of the winter. Apple trees that are in proper condition at the opening of the winter are found able to endure a much lower temperature and for a longer period than those that for any reason are not in good condition.

At the present time there are fifty-one trees of thirty-five varieties standing in the original orchard. These trees are for the most part those which are given elsewhere as of most promise. Most of them are in very fair condition, though there are several which are evidently in much poorer health than they appeared to be a year ago. Among the varieties to which special notice is called on page 305, those evidently in poorer health than last season are Red stripe, Sweet bellflower of Wyandotte County, Mansfield russet, Westfield seek-no-further, and Royal limbertwig. At least a part of these are evidently near their limit of usefulness. The varieties for this orchard which seemed most promising were in 
I894 topworked on two-year-old trees of Grimes, Duchess, and Whitney, and were planted this last spring (1896) in a new orchard for the sake of preservation and further trial.

\section{TESTING VARIETIES.}

Testing varieties at this Experiment Station has in the main proved unsatisfactory. Those who have done most of it would be the most ready to caution against placing too great confidence in the results. Where, as in this case, well known standard varieties, which all our fruit growers recommend with confidence, fail either in part or wholly, while others practically unknown succeed, it must make one cautious about recommendations, and yet the results must be given some weight. After making allowance for varieties behaving differently at another time or in another place, it has seemed to the writer that if he were confined to the list of varieties recommended by the State Horticultural Society or to another, which could be made up from those grown in the experiment orchard, he would take the latter. This would be especially true for the varieties recommended for summer and fall use.

The varieties which have given promise of the highest and most continuous value taken in order of their season of ripening have been the following, of which full descriptions may be found on pages 307 :

\section{List of Apples which have given the greatest Promise, arranged in Order of Season.}

William Prince, Red stripe, Hicks, Cole's quince, Large yellow Siberian crab, Jefferies, Sharp's, Utter, Jonathan of Buler, Sweet bellflower of Wyandotte Co., McLellan, Higby sweet, Mansfield russet, Westfield seek-no-further, Coon's red, Ned, Indiana favorite, and Royal limbertwig.

It must not be understood that this complete list is recommended to the exclusion of, or even in connection with, the varieties given by the State Horticultural Society, even for this locality. But the Red stripe, Hicks, Cole's quince, Large yellow Siberian crab, Jefferies, Sweet bellflower of Wyandotte Co., McLellan, Westfield seek-no-further, Ned, and Royal limbertwig have seemed to be of enough value to be recommended for the farm orchard to be planted either in place of, or in addition to, the varieties recommended by the State Horticultural Society.

Varieties for a commercial orchard are to be judged on a somewhat different basis from those for the family orchard. For commercial purposes fruit must be showy, of good size, uniform, 
ripening all at the same time, on the tree, firm enough to stand shipment without serious bruising, and productive. If to these can be added high quality, it is better; but quality is of less importance to the average buyer than appearance. Judged in this way, there have been few varieties found that could take a place in the commercial orchard. Perhaps the one that promises most value as a commercial variety is the McLellan, which ripens the latter part of September and may be kept until December. Westfield seek-no-further, which is a month or six weeks later, would stand next, and following these in order are Royal limbertwig and Cole's quince. Hicks seems to be a very desirable variety where a sweet apple of that season is wanted, but very few people care for sweet apples in a commercial orchard.

Of the varieties which are recommended by the State Horticultural Society and which were planted in the experiment orchard, Red Astrachan was not only a shy bearer, but the fruit was usually more or less imperfect. Sops-of-wine made good trees and bore some very fair crops, but it has not proved so good a fruit, or so productive, as red stripe of the same season. Early harvest scabbed so badly as to be almost beyond recognition. Red June bears fairly well, but it is too small, and apt to be scabby. Maiden's blush would not have attracted attention either from the quality or appearance of its fruit. F.all orange and Lowell have been no better in quality and have not borne so much or so perfect fruit as Utter or Jefferies. Jonathan and Grimes are about the same season as Westfield seek-no-further; all of them rank among the "best" in quality, but the Westfield has been decidedly more productive and the fruit has been larger and usually more perfect. Winesap as grown here has been too small, liable to scab and unproductive. Willow as planted proved to be short lived. Minkler, though making a good healthy tree, has always been unproductive.

Of the varieties which have been selected as of the most promise, the larger part are, according to the records, rather tardy in coming into bearing. Most of these trees were planted in 1869. Others were planted in 1870 and 1871. Only McLellan, Higby sweet, Coon's red, and Ned had attracted attention as of probable value as early as I879; Mansfield russet, Indiana favorite, and Royal limbertwig in 1884; Jefferies, Utter, and sweet bellflower of Wyandotte Co.; in $\mathbf{I} 886$, and the rest in $\mathbf{1} 888$. But the fruiting record of the orchard is incomplete and a variety may have given promise of value earlier than the record shows. 


\section{DESCRIPTIONS.}

In describing the fruits in the following pages the terms "good," "very good," and "best" have been used in reference to quality. A few writers have recently adopted a numeral system on the scale of ten to indicate comparative quality and some other characters, but the former method has the sanction of long use and to most readers the terms used would have more meaning than the numbers.

A few apples have been described by pomologists, which are classed as "poor ;" but usually they say that an apple which is not "good" is not worthy of either introduction or description, and so the lowest quality which is commonly ascribed to the apple is "good," and the great majority of apples are placed in this class.

Of the apples which Warder characterizes for quality eleven per cent. are classed as "poor," seventy-one per cent. as "good," fifteen per cent. as "very good," and three per cent. as "best." In Downing's characterizations of quality a larger per cent. is classed as "very good" and much smaller percentages as either "poor" or "best," while the proportion of "good" is very nearly the same.

The estimate which is placed on the quality of an apple is largely an arbitrary matter and will vary with the taste of the person. Most people seem to prefer a fruit of medium to one of very high quality; the very high flavor to which pomologists give the characterization of "best" being excessive to their tastes. To many people there is no other apple that is equal to the Rambo; but both Warder and Downing class it as "very good." I have heard people speak of the Sops-of-wine as one of the best of apples; but Warder and Downing agree in classing that as "good."

It will be found that in estimating quality of the varieties grown here, it has not in all cases been possible to follow the rating which Downing or Warder have placed on them; but it will be found too that they do not agree with each other all the time. The fact that varieties are not constant in character as grown in different places and that individual judgments are not the same, must be taken as the explanation.

The following descriptions have been made of the fruits in the list recommended, as they have been grown here:

\section{Descriptions of the Varieties of Apples which have given most Promise of general Usefulness.}

COLE'S QUiNCE.-Fruit, above medium size to large, roundish oblate, sometimes tapering toward the blossom end, yellow, with prominent white and russet dots, more or less ribbed, and somewhat irregular, sometimes compressed. Cavity, large, deep, ribbed, more or less russetted, sometimes lipped. Stalk, generally short and stiff. Basin, of 
medium size, ribbed. Calyx, closed. Core, rather large, and open. Seeds, large, dark brown. Flesh, yellowish white, rather coarse grained, tender, juicy when first ripe, becoming mealy as it passes the useful stage, subacid, mild, rather pleasant. Quality, very good for cooking. It could scarcely be classed as a dessert apple. It is usually at its best about Aug. Ioth to 2oth. The fruit ripens up evenly and may all be picked at once. The tree is a very slow, irregular grower, forming a low, compact spreading head, and is a regular and abundant bearer. Both tree and fruit have been comparatively free from disease.

The descriptions of this variety as given by Downing, Warder, and Thomas do not agree and neither of them is the same as the above in all particulars.

COON'S RED.-A variety not described under this name, and one which we have not been able to trace to anything else. It is said to have originated in Indiana. The fruit in some of its characters resembles the Baldwin, but is larger and more irregular.

Fruit, large, roundish oblate, often oblique, somewhat ribbed, or decidedly ribbed, at the apex. Skin, smooth. Color, pale yellow, mostly covered with rather rich, red, slightly marbled or sometimes faintly striped; dots, scattered, russet, or fawn color. Cavity, deep, rather narrow, more or less russet, almost regular. Stalk, short, thick, often knobbed. Basin, broad, more or less ribbed. Calyx lobes, broad, recurved; eye, very broad, large, open. Core, small, open. Seeds, stout, very plump, brown. Flesh, yellowish, fine grained, very tender, breaking, juicy, mild, pleasant, subacid. Very good. Use, dessert or kitchen. Season, from last of October to January, or later. The tree has been among our best bearers, and the fruit is large and very handsome.

Tree, a fairly large grower, making a broad, roundish, regular full head; branches stiff, somewhat irregular in growth, the lower horizontal.

Hicks.-Synonym, Buckram. Fruit, large, regular, or somewhat ribbed, sometimes compressed, round, yellow or greenish yellow, specked, splashed, and striped with dull and bright red, sometimes almost with an appearance of being shaded with red; dots, greenish with white centers, conspicuous. Cavity, of medium size, usually russetted, not regular. Stem, medium to long, variable in shape. Basin, medium to large, plaited. Calyx, large, open or closed; eye, large. Core, somewhat open; cells, short and full. Flesh, yellowish, juicy, becoming mealy or sometimes watery, very pleasant sweet taste, moderately rich. Quality scarcely more than good. In season from July Ioth to August Ioth; season long. Use, baking, dessert, or stock. The tree is an upright, vigorous grower and a good bearer, but not apparently so hardy as it should be for this locality. The apples when well developed have a fine appearance, and it may be eaten with relish when half grown. Since this variety first attracted attention it has been one of our best and most regular bearers.

HigBY SWEET.-Fruit, of medium size, regular, roundish oblate conic, pale waxen yellow with a pale red, though clear and handsome blush, and a thin white bloom; dots, scattered, pale or russetted and cracked. Cavity, of medium size, regular or sometimes lipped, mone or less russetted. Stem, medium to long, slender. Basin, medium, rather abrupt, plaited. Calyx, closed. Core, quite small, closed, regular. Seeds, short, plump. Flesh, quite white, fine grained, tender, juicy, spicy sweet, with a fine delicate flavor that is exceedingly pleasant to the taste. Season, October and November. Use, dessert.

The tree is a fairly regular grower and has been a moderate and regular bearer, but the fruit does not always come to perfection. When well grown and ripened, it is one of the most handsome of apples.

INDIANA FAVORITE.-Was planted for Green sweet but does not answer to the description of that variety.

Tree, large, spreading, somewhat open and irregular. Many of the branches have a peculiar growth on them which reminds one of the common toadstool found on dead trees, except that it grows close to the branch instead of extending out. 
Fruit, medium to large, flattened, narrowing towards the eye, almost regular, pale lemon yellow, shaded and splashed over most of the surface with red, and with a whitish over color; dots, large, rough, irregular in shape. Cavity, above medium, regular, russetted. Stalk, varying from short and thick to long and slender. Basin, usually small, shallow, plaited. Calyx, medium, closed. Core, medium size. Seeds, dark brown, plump. Flesh, yellowish white, a little coarse, moderately tender, juicy, mild, pleasant subacid, rich, almost, sweet. Very gooci in quality. Season, from November to March or A pril where well cared for. The trees have been fairly regular though seldom heavy bearers. The fruit is somewhat similar in appearance and character to Minkler, but is somewhat smaller and the trees have been decidedly more productive.

JEFFER1ES.-Fruit, of medium size, oblate, inclining to conic, regular, pale yellow, striped, splashed, or marbled with red, with blotches of crimson: dots, medium, light colored, very conspicuous, often heavy dark or russet. Cavity, medium size, regular, slightly russetted. Stem, short and small. Basin, of medium size, round, regular. Calyx, closed. Flesh, yellowish, very tender, juicy, with a rich, mild, very pleasant subacid flavor; quality, best for eating or cooking. Core, very small. Seeds, large. Season, August zoth to September 15th. The variety has borne with fair regularity. and sometimes very heavy crops.

The tree is a large grower, with rather long, upright, regular branches, vigorous, liardy and healthy.

JoNATHAN OF BULER. - Fruit, rather large, oblate, scarcely regular, somewhat ribbed. Color, greenish yellow, dotted, marbled and splashed or striped over most of the surface with red, with a thin bloom when first gathered; dots, white or russet, small. Cavity, rather large, broad, nearly regular, sometimes russetted. Stalk, short, thick, almost buried in the cavity. Basin, deep, abrupt, irregular, plaited. Calyx, large, closed; segments, nearly erect; eye, small. Core, very small, open. Seeds, numerous, very short, thick. Flesh, white, fine grained, tender, juicy, pleasant subacid. Use, cooking or would be fair for the dessert. Season, September and October.

The tree is a large, spreading, upright, scarcely a regular grower, and a fairly good bearer. It is a frutt worthy of further trial, and may prove to be an old variety misnamed. The name given would seem to indicate either a mistake or a lack of acquaintance with names of varieties. The varieties with which this most nearly agrees according to the descriptions by Downing are Brown, Flake's fall, Latham and Burkingham.

LARGE ÝELLOW SiBERIAN CRAB.-Fruit, small, or, for a crab, large, roundish oblong, somewhat ribbed, clear waxen yellow with a thin white bloom and occasionally a faint blush where exposed to the sun; dots, very'small, white, indistinct except about the blossom end. Stem, slender, about one inch long. Cavity, deep, narrow, nearly regular, sometimes slightly russetted. Basin, little or none, pinched and plaited. Calyx, tightly closed, with long segments. Core, small, closed. Seeds, small, slender, pointed. Flesh, yellowish, fine grained, very tender, very juicy, mild, pleasant subacid. The best in quality of the Siberian crabs. Excellent for the dessert, jelly, or sauce. The skin is very tender as well as the flesh and the fruit is easily bruised and shows bruises quickly, thus barring it from the list of market apples. The season is August 5th to 25th.

The tree is an upright spreading grower, rather small. Has not yet shown any tendency to blight or other disease. This has been the most productive and regularly bearing variety in the orchard, and this, with its high quality, makes it specially desirable for the family orchard.

MCLELLAN.-Fruit, large, nearly regular, somewhat ribbed, roundish oblate, sometimes inclined to be oblong; light yellow, shaded or marbled sometımes over the whole surface with light red, rather dull, and occasionally indistinct splashes of darker red; dots, few, gray or russet. Stem, short. Cavity, broad. not very deep, often with one or 
more lines out from it. Basin, small to medium, abrupt, usually ribbed. Calyx, usually closed, rather long, slender; eye, small, deep. Ovary, small, regular. Flesh, whitish, very tender, juicy, mild, pleasant subacid. Season, September to November, or later. Use, dessert, kitchen, or market.

Tree, an upright, regular, rapid grower and a regular and fairly abundant bearer, bearing almost annually. Its fruit is always smooth and attractive. This does not agree with the apple as described by either Downing or Warder under the same name. It answers very well the description given for Ohio or Negus's Nonpareil.

MANSFIELD RUSSET.-Fruit, quite small, roundish or oblong, almost narrowing toward the apex, more or less ribbed; pale yellow, shaderl or marbled with dull red and with irregular patches of thin russet; dots, russet, small, inconspicuous. Cavity, medium, broad, shallow, often lipped. Stem, long, slender. Basin, comparatively broad, shallow, ribbed. Calyx, closed; long slender segments. Core, small, slightly open. Seeds, small, numerous. Flesh, almost white, very fine grained, almost melting, moderately juicy at first but becomes rather dry, very mild and pleasant subacid, moderately rich, very good to best in quality. Use, dessert. Season, October to the holidays.

The tree is spready, rather irregular grower, large, and produces large crops at least on alternate years and seldom fails entirely. The objection to the variety is its small size. It would be a desirable apple in many amateur orchards where considerable variety is an advantage, but would have no place in the ordinary commercial orchard.

NED._Fruit, medium, or above, roundish oblate; greenish yellow, mostly covered with light red, shaded and dotted with darker red; dots, very large, gray, with dark centers. Stem, medium to long. Cavity, rather large, inclined to be somewhat threecornered, russetted. Basin, broad, shallow, plaited. Calyx segments, large, short; eye, broad, deep. Core, small. Seeds, very small, dark brown. Flesh, nearly white, juicy, very tender, pleasant, mild, subacid. Use, dessert or kitchen. Quality, while pleasant is only good. Season, November to January.

The tree is a very large grower, with a full broad head and branches somewhat inclined to be drooping. It has been a regular and often very full bearer. Hardy and free from disease. It seems worthy of recommendation for the home orchard.

RED STRIPE.-Fruit, medium size, oblong conical, irregular ribbed; clear, light waxen yellow, specked, and splashed with clear light red when full ripe; dots, very small, numerous, whitish, inconspicuous. Stalk, medium, curved. Cavity, medium size, narrow, usually russetted. Basin, narrow, shallow, abrupt, plaited. Calyx, closed; segments, long, slender, recurved; eye, small. Core, large, open. Seeds, numerous, small, brown. Flesh, yellowish, firm, juicy, rather rich, pleasant subacid. Use, dessert or cooking, for either of which the quality is very good. The apples are very apt to be imperfect from scabbing.

The tree is an abundant and regular bearer. The fruit ripens very unevenly and so is not specially desirable for the commercial orchard. The fruit begins to mature about the middle of July and continues for six weeks, giving it a very long season, which makes it the more desirable for the farm orchard. The greatest objection to it is liability to scab.

Royal Limbertwig.-There is no Royal limbertwig described and this variety is distinct from other limbertwigs grown here, both in tree and fruit. Mr. Lawver said the variety came to him from North Carolina but did not give the introducer. Fruit, of medium size or above, oblate, quite regular, with a limbertwig color; greenish yellow, marbled with dull red; dots, fawn color, with dark centers, very conspicuous. Cavity, of medium size, regular, russetted; stem, medium length, slender. Basin, medium size, rather broad and shallow, slightly wavy. Core, small. Seeds, short and plump. Flesh, yellowish, tender, pleasant subacid moderately rich. Good to very good quality. Use, dessert or kitchen. Season, December to June. 
The tree is a medium grower, forming a full regular rounded head, with but little of the limbertwig habit of growth.

SHARP'S APPLE.-There is no variety described under this name and it does not agree satisfactorily with any that is described. Mr. Lawver obtained it from Halliday \& Son, Baltimore, Md., but I have not succeeded in tracing it further.

Fruit, small to medium in size, more or less ribbed, smooth, becoming almost oily; color, light waxen or greenısh yellow, with a full red or pinkish blush and with a thin white bloom; dots, small, scattered whitish, inconspicuous. Cavity, medium size, open, regular, often with more or less russet, the russet forming short lines out on the base of the fruit. Stem, $1 / 2$ to $3 / 4$ inch long, slender. Basin, medium, rather abrupt, wavy. Calyx. closed; segments, short. Core, small. Seeds, medium size, short, very plump. Flesh, almost white, very tender, very juicy, exceedingly pleasant subacid, almost sweet, moderately rich. Quality, very good for dessert. Season, September and October.

The tree is a regular grower, forming a broad, full, upright head, and it has been a regular and abundant bearer. The small size of the fruit would render it unmarketable. It would only be recommended for the amateur.

SWEET BELLFLOWER OF IVYANDOTTE COUNTY.-Fruit, large, regular or nearly so, roundish conic, or almost ovate; skin, greenish yellow, rough, often thinly russetted, occasionally a bronzed cheek; dots, large, russet, raised. Cavity, deep, rather narrow, regular, with more or less russet. Stem, long, slender. Basin, small, narrow and deep, plaited. Calyx, closed; segments, usually long, slender and recurved; eye, small. Core, small, nearly closed. Seeds, short and thick. Flesh, yellowish, coarse grained, not very juicy, firm, half tender, rather rich, sweet.

The tree is a moderate grower, upright spreading, becoming drooping, regular, and a good bearer. Good for baking, preserves, or stock feeding. Season, middle of A ugust to middle of October. Although it could only be classed as good and is not specially attractive in appearance, it would seem to be worthy of more general cultivation.

This fruit is in appearance somewhat similar to the Pumpkin sweet of Thomas, but differs in being more conical, having raised dots, occasional blush, and of being not so good in quality. This tree is almost a Willow twig in appearance, while the other is more irregular, with branches much stronger and stiffer.

UTTER.-Fruit, large, oblate, conic or roundish conic; pale yellow, marbled and splashed with light red in the sun, with but little red in the shade; dots, white or russet, not conspicuous. Cavity, medium, nearly regular, usually slightly russetted. Stem, small. Basin, wide, shallow. Ribbed toward the eye. Calyx, closed. Core, small, nearly closed. Seeds, short and plump. Flesh, yellowish, firm, crisp, moderately tender, juicy, pleasant subacid. Quality, very good. Use, dessert or kitchen. Season, middle of August to first of October, and may with care be kept until the first of December, though it loses much of its quality on keeping so late.

The tree is a rather upright, regular grower, forming a full rounded head, has been exceptionally free from disease and has borne very well. It promises to be of value for either home use or market.

WESTFIELD SEEK-NO-FURTHER.-Fruit, medium or above, roundish conical, somewhat irregular; greenish yellow, shaded and striped, usually with red, often having the appearance of being thinly russetted; dots, not numerous, rather large, usually russetted, the russet extending out over the apple in lines or irregular patches. Stem, medium to long, curved. Basin, small, regular, cracked. Calyx, medium, nearly closed, recurved at the points; eye, broad, not very deep. Core, open. Seeds, small, sharp pointed, numerous. Flesh, yellowish, tender, breaking, molerately juicy, very rich, mild subacid. Season, October to January. Quality, very good to best. Use, dessert or kitchen.

The tree is a moderate grower, upright, spreading, moderately healthy, and has been a regular and often abundant bearer. The fruit is liable to fall too early and then 
does not keep, which seems its greatest fault. It certainly seems desirable as an amateur's apple, but is not showy enough and does not keep well enough for market.

William Prince.-No variety is described under this name, and Mr. Van Deman, formerly Pomologist to the Department of Agriculture, Washington, D. C., says it may De Early red Margaret. Fruit, variable in size, from almost small to full medium; oblate conic with some irregularity of outline; pale greenish yellow, with a thin white bloom, and conspicuous white dots, with a few light red stripes and splashes or dots. Stalk, of medium length, rather thick, usually bracted. Cavity, nearly regular, heavily russetted. Basin, small, uneven, pinched. Calyx, closed; segments, very large. Core, small, closed. Seeds, small, very plump. Flesh, white, very tender, juicy, very mild, pleasant subacid. Fruit tends to become either water-cored or mealy as it ripens fully. Good to very good either for cooking or eating. Season, last half of July, ripening before Early harvest or Red Astrachan. It has been a heavy bearer alternate years with little or no fruit the off year.

The tree is at first rather upright, but becomes spreading with age and bearing. A rather slow grower, but healthy and hardy. Young twigs, reddish brown, downy. This has been one of our best early apples. While not as good as Duchess for cooking, it is much better as a dessert apple when in season.

\section{Brief Descriptions of other Varieties which have Fruited on the Experiment Station Farm.}

A.-Two trees were planted. One died previous to $188_{4}$, the other bore fair crops of fruit in 1884 and 1886 , and was taken out in $1888-9$. The fruit matured in fall and was considered of no value.

ABERDEEN.-One tree was planted. It bore a few apples in $188_{4}$ and was dead in I\$86. Fruit, large, roundish, yellow, subacid. Summer. Downing gives Aberdeen as a synonym of Nickajack, which is a winter fruit.

ABRAHAM. - One tree was planted. It bore a few small apples in $188+$ and $\mathrm{I} 856$ and was taken out in I888-9. Fruit, yellow, subacid, very good in quality. September and October. Of no value.

AIsLes - Two trees were planted. These bore a few apples in 1878 and 1879 and fair crops in 1886 and $I 888$. The trees were taken out in 1892 . Fruit, of medium size, oblate, irregnlar; striped red, subacid, very good in quality. Late winter. Too unproductive.

A LLEGHANY SPOT.-Three trees were planted. Two of these had died previous to I 884 and the other was in poor condition when taken out in I886-7. The variety bore apples in 1879,1884 , and I886. Fruit of medium size, only good in quality. Autumn.

Alexander.-One tree was planted. It bore fair crops in 1886, I888, I889, and I89I. The fruit was always more or less imperfect and liable to rot; though very showy when in perfection, it was of comparatively little value. Tree, large, vigorous, healthy. Fruit, large, striped red, acid, very good for cooking. Last of August and September.

AMERICAN BEAUTY.-Five trees of two different varieties were planted under this name, one a fall and the other a winter fruit. The former was evidently incorrect. The varieties bore medium crops in 1878 and 1879 , and good crops in 1884 and 1586 . The winter apple American beauty was voted promising in 1878 , not valuable in 1879 , a good keeper and worthy of trial in 1884 . All the trees had diell or were in poor condition in 1886 and were taken out soon after. Fruit, large, roundish, striped red, subacid, aromatic, very good in quality. Late winter.

AMERICAN NONPAREIL.-Seven trees were planted. Five of the trees had died previous to 1884 and the other two were in fair condition in I886, but were taken out soon after. These bore a few apples in I884 and I886. Fruit, small, good in quality, badly subject to scab. Midsummer. 
AMERICAN PIPPIN.-One tree was planted under this name, which proved to be Roxbury russet. See under Marietta russet, p. 331. For the true American pippin, see Shannon, p. 340.

AMos J ACKson.-Synonym of fackson. Three trees were planted. The variety bore a few apples in $1878,1879,1886$, and 1891 , and fair crops in 1884 and 1888 . It was considered to be worthy of further trial in 1879 , but was taken out in 1893 , because too unproductive. Fruit, medium size, oblate, yellow with a brownish blush and russet markings, brisk subacid, good. Late winter.

ANDERSON.-One tree was plarited. This bore a small crop in 1884 . but was dead in 1886 . The fruit was of medium size, only good in quality, ripe in fall. The variety as described to Mr. Lawver originated in South Carolina, and was a good keeper.

ANJOU PIPPIN.-One tree was planted. It bore a few apples in 1878 and 1879 , but was dead previous to 1884 . Lawver received it from Elwanger and Barry, who gave its origin as France. Fruit, large, oblate, conic, sour, with large angular dots. Very like Dominie.

Ashmore.-Two trees were planted. These bore a few apples in $188 \mathrm{I}$, and small crops in 1884 and $\mathrm{I} 886$. The variety was considered promising in $\mathrm{r} 88 \mathrm{I}$, but was taken out in 1889 , as of no further value. Fruit, large, of very good quality. Late winter.

AUGUSTA PIPPIN.-Three trees were planted in two different parts of the orchard. There were evidently two varieties planted under this name, since the fruit is spoken of at one time as "fine, large, golden yellow" and at another as "red striped." Two of the trees died previous to 1886 , and the other was taken out in 1889 as of no further value.

AUnT Susan's Favorite.-Two trees were planted. One of them died previous to $I 886$, and the other was taken out in 1887 . The variety bore a few apples in 1884 , and again in 1886 . Fruit, of medium size, oblate, yellow, striped red, subacid, best in quality. September and October.

Austin PIPPIN.-Two trees were planted. These bore a good crop in $188_{4}$. One of the trees had died before 1886 , and the other was in such poor condition that it was taken out soon after.

AUTUMN STRIPE.-One tree was planted which proved to be the same as Chenango strawberry. See p. 317 .

BACCATUS CRAB. -One tree was planted. It bore good crops in 1872 and 1886 , and a few apples in 1884 . The tree was taken out in 1887 . Fruit, small to medium for a crab; yellow with a blush of red. Quality, good.

BALM.-Two trees were planted. The variety bore a few apples in 1878 , 1879 , I884, and I886. At the latter date one of the trees was in fair, and the other in poor, condition. Both were taken out the next year. Fruit, medium size, only good in quality. October, or later.

BARD.-One tree was planted. It bore a few apples is 1878 , I879, and 1886 , and was cut out in 1887 . Fruit, medium to large, dark red, poor in quality. Winter.

BARRETT. - Two trees were planted. They bore a good crop in 1877 , and a few apples in 1879 . Both trees died previous to I884. Fruit, medium to large, oblate, yellow, marbled and striped light crimson. subacid. Quality, good. Winter.

BASTARD JANET.-Synonym of Wright's fanet. Two trees were planted under the former name and two under the latter. The two Wright's fanet died without fruiting; the others bore a few apples in 1884 and $\mathrm{r} 886$ and a fair crop in $\mathrm{r} 888$, and were taken out in 1892 because too unproductive. Fruit, medium size, oblate, yellow, somewhat splashed with dull red, subacid, brisk. Quality, good to very good. Late winter.

BeAchemwell.-Two trees were planted. One died the next year and the other in 1885 . A few apples were borne in 1877 . Fruit, small, yellowish, brisk subacid. Of little comparative value. 
BEAUTY OF THE VALLEY.- One tree was planted. It bore a few apples in i 384 and a fair crop in $\mathbf{1} 386$, and was dead soon after. Fruit, small, very good in quality. Winter.

BELLE.-One tree was planted under this name. It bore a few apples in 1878 and 1879, and was taken out in 1887 . Fruit, small, sweet, of poor quality. It was described to Mr. Lawver as of "southern origin, large red, beautiful, fine keeper."

BELLE ET BONNE.-Two trees were planted under this name, and two more, which proved to be Belle et bonne, were planted under the name of Bristol. One of the trees planted as Belle et bonne was the same as Moore's sweeting, and the other proved true. The variety bore fruit in $1873,1879,1834$, and 1886 , and all the trees were taken out in I889. Fruit, large, oblate, irregular, subacid, yellow. Quality, very good. October.

Benoni.-One tree was planted under this name, but it proved to be an unknown winter apple. The Benoni has been grow $\mathrm{n}$ in another orchard here and is a well known valuable summer apple, especially for home use. Fruit, of medium size, roundish, striped and nearly covered with red. Flesh, yellowish, rich, pleasant subacid. One of the best in quality. August. Tree, an upright compact grower and a fairly regular bearer.

BentLey's sweET.-Five trees of two varieties were planted under this name. One of the varieties was a worthless winter sweet apple, and the other proved to be the same as Hicks, p. 324 .

BERGNER.-Five trees were planted. All but one of these were dead previous to I886, at which time the remaining tree bore a few apples. It was considered worthless, and no description was made.

BETSEY.-One tree was planted. It bore fair crops in $1878, \mathbf{1} 879, \mathbf{1 8} 86$, a few apples in 1834 , and a full crop in 1888 . The tree was taken out in 1889 . Fruit, below medium size, roundish, oblate, yellow, often slightly blushed, mild subacid, pleasant. Quality, good. Late winter. Too small to be of value.

BeTsey's FAvorite.--Two trees were planted. These bore a few apples in I380 and a fair crop in 1886 . Fruit, below medium size, yellow, mild subacid, only good in quality. The trees were taken out in 1889 , because not considered of further value.

BEVERLY. - Two trees were planted. One died previous to 1884 ; the other bore a few apples in 1886 and was taken out in 1887 . The fruit was considered of no value here, and no description was made of it.

BLACK APPLE. - Three trees of two varieties were planted under this name. Neither variety seemed of any value, and the last of the trees died in $\mathbf{I} 887$.

BLACK COAL. - Two trees were planted. They bore a few apples in 1878 and a light crop in 1879 . The trees died in 1885 . Fruit, medium to large, roundish, dark red, crisp, subacid. Quality, good. Winter.

BLACK JACK.-Synonym of Black apple. Two trees were planted under this name, one of which proved correct, the other not. The Black Fack bore a few apples in ${ }_{1} 878$, $\mathrm{r} 88_{4}$, and $\mathrm{I} 836$. Fruit, of medium size, roundish, deep red, subacid, only good in quality. The trees were in good health when taken out in 1877 .

BLAKESLY SEEK-NO-FURTHER. - Two trees were planted in different parts of the orchard. The variety bore a fair crop in 1884 , and a few apples in 1886 . No description was made of the fruit. One of the trees died in $133_{5}$, and the other, nearly dead, was taken out in 1887 .

Blinkbonny.-Three trees were planted in two different parts of the orchard. A few fruits were borne in 1877 and 1884 , and a fair crop in I386. Fruit, below medium size, oblate, pale yellow, subacid. Quality, good. Early summer. Thetrees were taken out in 1887 as of no special value.

BLocklEy. - Two trees were planted. They bore a half crop in 1378 and a fair crop in 1879, but where dead in 1884. Fruit, large, conical, fine yellow, subacid. Quality, very good. Early winter. 
Blondin.-Two trees were planted. One died previous to 1884 , and the other, though in poor condition, bore a few apples in 1884 and 1886 , and was taken out in 1887. Fruit, large, striped red, scarcely good in quality.

BLooming orange.-Two trees were planted. These bore a few apples in 1878 and I879. Fruit, large, oblate, striped with red, acid. Quality, very good. Season, September. One of the trees died in 1885 , and the other was taken out in 1887 .

Blue Mountain.-Two trees were planted. The variety bore a few apples in 1878 and 1879 , a fair crop in 1884 , and a full crop in 1886 . Fruit, medium to large, striped red on pale yellow, subacid. Quality, good. Winter. One tree died previous to 1884 , and the other was in poor condition when taken out in 1887 .

BLUfF PEARMain.-Two trees were planted in different parts of the orchard. These bore a half crop in 1878 and a full crop in 1879 , and both died previous to 1884 . The, fruit was very similar to Razule's fanet.

BoAs. - Three trees were planted, two of which died previous to 1884 . The other, though in poor health, bore a few apples in 1884 and 1886 and was taken out in 1887 . Fruit, medium size, good in quality. Early winter.

Bonum.-One tree was planted under this name, which died in 1873 . Two others were planted in another part of the orchard under the name of Red Bonum, which proved to be Bonum. One of these trees died previous to 1884 , and the other in 1887 . The variety bore a full crop in 1877 and a few apples in 1884 and 1886 . Fruit, of medium size, roundish, nearly covered with dull red, subacid. Quality, very good. October and November.

BORSDORFFer.-Two trees were planted. They bore a fair crop in 1886 and were taken out the next year. Fruit, small, roundish, pale yellow with red cheek, brisk subacid. Very good. Late fall.

BougH.-Two trees were planted under this name. One of them died previous to $188_{4}$, and the other bore a fair crop in 1884 and a few apples in I886. It was taken out in 1857 . The fruit was large, but otherwise of no special merit.

BOULER'S FAVORITE. - One tree was planted. It bore a few apples in 1878 and 1879 , and was taken out in 1887 . Fruit, large, oblate, oblique, striped red and russetted. acid. Quality, very good. Winter.

BRANDYWINE.-Synonym of Minkler. Three trees were planted in two different parts of the orchard. These bore a few apples in $1877,1878,1879,1884$, and 1886 and a small crop in $1888^{\circ}$. Two of the trees were taken out in 1887 , and the other, though left until I 892, did not bear more than a few apples. While the Minkler or Brandywine is recommended by the State Horticultural Society for all parts of the state, it has been a very shy bearer with us, both in this orchard and in another planted in 1879 . Fruit, rather large, roundish, oblate, shaded red on greenish yellow, very mild, subacid. Quality, very good. Late winter.

Bristol.-Two trees were planted under this name, but both proved to be Belle et bonne.

Brown.-One tree was planted. It bore a few apples in 1878 and 1879 and was dead in 1884 .

BROWN'S SUPERIOR.-Two trees were planted. One died without fruiting, the other bore a few apples in 1884 and died the next year. It was a summer fruit of medium size and only good in quality.

BROWN'S SWEET. - Three trees were planted in two different places in the orchard. The variety bore a few apples in 1879 and 1884 and a fair crop in 1886 . One of the trees died previous to 1884 , another in 1885 , and the third was cut out in 1887 . The fruit was small, sweet. Only good in quality. Winter. Of no apparent value.

Buchanan PIPPIN (?).--One tree was planted. It bore a few apples in 1879 , but was nearly dead at that time. 
Buckram.-Synonym of Hicks. Two trees were planted. According to the record they bore a large crop in $188+$ and a good crop in 1886 . The trees were taken out in 1887 .

Buckingham.-Two trees were planted. A few apples were borne in I886, but the trees were in poor condition when cut out in 1892 .

Bucks County Pyppin.-Two trees were planted. A few apples were borne in 1878 and 1879 . One tree died previous to 1884 and the other in 1887.

BUEL'S FAvORITE.-One tree was planted. It bore a few apples in 1877 and fair crops in 1884 and 1886 . The tree was taken out in 1887 .

BuFF.-Four trees were planted in two different parts of the orchard. A few apples were borne in 1876 . All the trees had died previous to 1884 .

BULl HEAD.-Two trees were planted in two different parts of the orchard. A few apples were borne in I886. The trees were in fair condition at this time but were taken out in 1887 .

BULLOCK's PIPPIN.-Two trees were planted. One of these proved to be fiarvest red streak and the other died without fruiting.

BURChardT.-Two trees were planted. A few apples were borne in 1875 and I879 and the trees died previous to I884. It was a winter fruit, yellow and russet. Size, small to medium, only good in quality.

BURLEY'S SWEET.-One tree was planted. It bore a few apples in 1878 and I879 and was dead previous to I884. A yellow sweet, winter apple of medium size, only good in quality.

BUSHWHACKER.-Two trees were planted. These bore full crops in 1878 and 1879 and died previous to 1884 . It was a large green winter fruit, of very good quality and was considered promising in 1879 .

BYERS. - Three trees were planted in two different parts of the orchard. One tree bore a fair crop in $\mathbf{1} 884$, the other two had died previously, and the remaining one died in 1885 .

CABbage head.-Four trees were planted in two different parts of the orchard. A few apples were borne in 1878,1879 , and 1884 , and a fair crop in I856. At the latter date but one tree was alive. It was in fair condition, but was taken out the next year. The fruit was of medium size, good to very good in quality. Winter. Not considered of value.

CABLE'S Gilliflower.-Synonym of Baltimore. Two trees were planted. One of them bore no fruit, and was evidently not true to name. A few apples were borne in 1877 and fair crops in 1878 and 1879 . Both died in 1885 .

CAMACK's sweEt.-Two trees were planted. A fair crop was borne in 1884. One tree died in 1885 and the other was taken out in poor condition in 1887

CAMPFIELD. - Seven trees were planted in two different parts of the orchard. A few apples were borne in 1878 and 1879 . Three of the trees died previous to $18 S_{4}$ and the rest in 1885 . The fruit was small, scarcely good in quality, worthless.

CANADA.-Two trees were planted. Fair crops were borne in 1878 and I879. All the trees died previous to 1884 . The fruit was of medium size, deep crimson with white flesh. Quality, good. Winter.

CANn.-Three trees were planted. A good crop was produced in $188 \mathrm{~A}$. Fruit, small, only good in quality. Season, winter. Not at all promising. It was probably not true to name. Two of the trees died in 1885 , and the other was taken out in 1887 .

CAPTAIN.-Two trees were planted which proved to be the same as Red Astrachan. A fair crop was borne in 1886 , and the trees were taken out in 1887 .

CARDINAL RED.-Three trees were planted. These bore some fruit in 1877 , a fair crop in 1886, a full crop in 1888 , and a few apples in 1889. The trees were all taken out in 1890 . The fruit is medium to large, dark, rich red, showy, only good in quality. Midwinter. It was not considered worthy of propagation. 
CAROLINA RED.-Three trees were planted in two different parts of the orchard. A fair crop was borne in 1877 and a few apples in 1884 . Two of the trees had died previous to 1884 and the other was in poor condition and died soon after. Fruit, medium size, only good in quality. Winter.

CARPENTER.- Two trees were planted. A fair crop was borne in 1884 , and the tree died soon after. Fruit, small, good in quality, Season, winter. It was thought to be worthy of further trial.

CARTER (of Alabama).-Two trees were planted. A fair crop was borne in 1884 , and a few apples in 1886 . One tree died in 1885 and the other was taken out in 1887 . Fruit, small and only good in quality.

CARTer (of Pennsylvania).- Two trees were planted. A few apples were borne in 1856 . The fruit ripened in early winter and was considered worthy of further trial. The trees were taken out in 1857 .

CARVER (of New York).-Two trees were planted, which proved to be the same as Red Astrachan. One tree was dead in 1884 . A fair crop was borne in 1884 by the other, which died in 1885.

CATHEAD.-Three trees were planted and all those bearing fruit proved to be Hicks.

CELESTIA.-Two trees were planted, which proved to be the same as Cardinal red.

Champagne. - Two trees were planted in different parts of the orchard. A few apples were borne in 1878 and 1879 . One tree died previous to 1884 and the other in 1885. The fruit was of medium size, striped, of good quality. Winter. It is not recommended.

CHANCELor OF OXFord.-Two trees were planted. A few apples were borne in $I S 7 S$, I 879 , and $I 884$, and a fair crop in 1886 . One tree died previous to 1884 , and the other was taken out in 1887 . Fruit, small to medium size, good to very good, yellow, nearly covered with red stripes. August.

Chenango strawberRy. - Two trees were planted under this name. One of them died without fruiting, and the other bore such inferior fruit as to lead to the opinion that the tree was from the root used in grafting, and not from the cion. Another tree planted under the name of Autumn stripe proved to be Chenango strawberry. It bore fair crops in $1884,1886,1889$, and 1895 , a full crop in 1888 , and a few apples in 1890,1892 , and IS94. Fruit, medium size, striped red, with a bloom; subacid, pleasant. Quality, very good. Late summer.

CHESTER RED STREAK.-Two trees were planted in different parts of the orchard. Fair crops were borne in 1884 and 1886 . It was considered of little value. One tree died in 1885 , and the other was taken out in 1887.

Chenvor.-One tree was planted. It bore a few apples in 1878 and 1879 , and fair crops in 1884 and $\mathrm{I} \$ \$ 6$. The fruit was medium to large, light yellow, sweet and in 1879 was considered promising. The tree was taken out in 1887 .

Chronical.-Four trees were planted. A few apples were borne in 1877,1878 , I879. IS84, I886, I890 and $I 89 I$, and a fair crop in $I 888$. The fruit is of medium size, greenish yellow with dull red, subacid, good in quality, and a very late keeper. The tree is an upright, regular grower, with a rather dense head. It was considered promising in $\mathrm{I}_{7} 8$ and $\mathrm{I} \mathrm{S}_{79}$ but was taken out in $\mathrm{I}_{892}$ as not worthy of further attention.

CIDER.-Four trees were planted under this name. A few apples were borne in 1878 , 1879 , and 1884 and a fair crop in 1886 . The fruit was small, of good quality. August. Almost worthless. The trees were taken out in 1887 .

CLARKE.-One tree was planted. It bore a few apples in $188_{4}$ and 1886 . The tree was in poor condition both years and was taken out in 1887 . The fruit was small, of good quality, but of no value. 
Clarkson.-Two trees were planted under this name, both proving not true, but to be the same as Cardinal red.

Clarke pearmain.-Two trees were planted. One tree died previous to 1884 , the other bore a few apples in 1886 , and was taken out the next year.

Claudia de Provens. - Two trees were planted. They bore a few apples in 1878 , I 879 , and I88I, and all were dead previous to I884. Of little value.

Cogswell.-One tree was planted. It bore a few apples in 1878,1879 , and 1884 . Fruit, of medrum size, of good quality, mild subacid. October. The tree died in 1885 .

COLE'S QUINCE.-One tree was planted. It bore good crops in I884, I886, I88S, I894, a fair crop in 1895 , and a few apples in $1889,1890,1891$, and 1892 . A summer fruit of medium to large size and good quality. The season is about the same as Maiden's blush, to which it would seem to be decidedly superior under our conditions. A rather small grower, dense, and irregular. (See full description, p. 307.)

ColumBUS RED.-Four trees were planted in three different parts of the orchard. They bore a few apples in $1877,1879, \mathbf{I} 886, \mathrm{I} 89 \mathrm{I}, \mathrm{I} S 94$, and a fair crop in I88S and 1895. Fruit, medium size, yellowish, shaded with red. Quality, good. October to January. One tree died previous to 1884 , two others were taken out in 1887 , and the last in 1895 .

Columbia.-One tree was planted. It bore a few apples in $1877,1878,1879,1884$, ISS6. The tree was taken out in 1887 . Fruit, small to medium size, irregular, striped red, subacid. Quality, very good. Late fall or early winter. In I884 it was thought worthy of further trial, but in 1886 it was said to be too small to be valuable.

Conic JUNE.-One tree was planted. It bore a few apples in 1887 , and was dead soon after.

Connecticut RED SIDEs. - Three trees were planted in two different parts of the urchard. The variety bore a few apples in $1877,1878,1879$, and 1880 , and a fair crop in 1884 , and a good crop in 1886 . The fruit was about the size and shape of a winesap. Early winter or late fall. Of little or no value. One of the trees died in $188_{5}$ and the others were taken out in 1887 .

COOK's GREENING.-Two trees planted. They bore a few apples in 1885 and a fair crop in I886. The fruit was small, good to very good. The trees were taken out in 1887.

COON'S RED.-One tree was planted. It bore a few apples in ISS4, ISgo, and IS9I, fair crops in I8S6 and I895, and a full crop in I888. The tree still stands and is in good health. (See full description, p. 308.)

CoRSE'S FAvorite.-Four trees were planted. A few apples were borne in 1878 and 1579 , a fair crop in 1884 and 1893 , good crops in $1886,1888,1859$ and 1891 . The fruit was medium to large, oblate, yellow, only good in quality, subacid, not rich. Season, August.

It was a heavy and regular bearer but otherwise was not desirable. Three trees were taken out in 1887 and the other in 1893 . All were in perfect health when taken out.

CoUnTry sweEt.-One tree was planted, which proved to be Northern spy.

CreEK.-Three trees were planted. This variety proved to be the same as Ned. p. 3 IO.

Crooked RED.-Four trees planted under this name proved to be Pennock. p. 335 .

Crow's EGG.-Two trees were planted. A few apples were borne in $1 S_{7} 8$, IS79, and 1886 . The fruit was of medium size, good only in quality, sweet, of no value. The trees were taken out in 1887 .

Cullasaga.-Three trees were planted. A few apples were borne in 1850 and the trees were taken out in 1887 .

CUllawheE.-Two trees were planted. 'There was a fair crop in 1884 and a good crop in I886. The fruit was of medium size and poor in quality. Acid, striped. One tree died in 1885 and the other in 1887 . 
Cumberland seedling. - Two trees were planted. They bore a good crop in I886. The trees were unhealthy and were taken out in 1887.

CuShman's BLACK.-One tree was planted. It bore a few apples in 1878 and I879, a fair crop in I884, and good crops in 1836 and IS88. The tree was taken out in I89I. The fruit was medium to large, dark red, almost black, apt to be water-cored, pleasant subacid, very good in quality. Early winter. It seemed to be quite promising at one time.

CUSTARD. - Two trees were planted under this name, which proved to be the same as $\mathrm{Ned}$.

DANA GREENING.-Two trees were planted. These were thought incorrect in 1879 and 1880 but were considered correct later. A few apples were borne in 1874,1878 , I879, I89o, and I89I, a good crop in I884 and I888, and a fair crop in I886. One tree died in 1885 and the other was taken out in 1893 . Fruit, medium to large, greenish yellow, subacid, mild aromatic, very good in quality. Winter. It was considered worthy of further trial in 1880 , but in 1893 it was not considered of enough value to retain longer.

De Boutigne.-Synonym, Botigne. One tree was planted. It bore a few apples in 1878 and $I 879$ and died between 1830 and $I 884$. Fruit was of medium size, very good, aromatic, rich, but not sweet.

DE Gruchy.-Two trees were planted. A few apples were borne in 1878, 1879, and 1884 . The trees died in 1885 . Fruit, small to medium size; striped red; subacid, almost sweet; poor in quality. Winter. Of no value.

Des femmes. - Two trees were planted. A few fruits were borne in 1876 and 1877 and the trees died between 1880 and 1884 . The fruit is medium to large, somewhat like Baldzoin in appearance, acid. Winter.

Deterding's early.-Synonym, Red Astrachan. (See p. 337.)

DicksKiLl.-One tree was planted. It bore a few apples in 1878 and 1879 , and a fair crop in 1884 . The tree died in 1885 . Fruit, medium to large, striped, acid, of tender flesh, very good in quality. Early winter.

DR. FUlCher.-Four trees were planted. These bore a few apples in 1879 and a good crop in 1884 . All died in 1885 and 1886 . The fruit is small, only good in quality and not desirable.

DR. WhitSELL'S WiNTER.-One tree was planted. It bore a few apples in I884 and was taken out in 1887 . The fruit was of medium size, good in quality and a good keeper.

DominiE.-Five trees were planted. A few apples were borne in 1878 and 1879 and a fair crop of inferior fruit in I884. The trees were all dead in 1885. Fruit, medium to large, striped dull red on dull yellow, with large rough dots, subacid, very good. Winter. This has been considered a valuable apple in many places.

Doux D'ARGent.-One tree was planted. This bore fair crops in I 878 and I886, a full crop in 1879 , and a few apples in 1884 . Fruit, large, sweet, very good to best in quality. The tree was taken out in 1887 as nut worthy of further attention.

DownIng's FAvorite.-Three trees were planted. These bore a few apples in 1878 and 1879 and fair crops in 1884, I886, and I8S8. Fruit, medium to large, red striped, very good in quality. September. This seemed promising in 1879 , but the short life of the tree makes it unworthy. One tree died previous to 1884 , another in I885. and the third was in bad condition when cut out in 1892 .

DRAP D'OR.-One tree was planted. It bore fair crops in $1884, \mathrm{I} 888$, and $\mathrm{I} 890$, and a few apples in 1886 and 1889 . Fruit, large, pale yellow, subacid, very good in quality. A fine apple, but not productive enough. The tree was in excellent condition when taken out in 1893 .

DRUMORE.-Two trees were planted. Fair crops were borne in 1878 , I879, I884, and $I 886$. One tree died in 1855 and the other was nearly dead when taken out in 1887. 
Fruit was of medium size, red, good to very good in quality. Winter. Was thought worthy of further trial in 1879 .

Dubreil.-One tree was planted. It bore a few apples in 1884 and 1886 . The tree was nearly dead when taken out in 1887 .

DUcket.-Two trees were planted. These produced fair crops in 1884 and 1886 . The trees were in fair condition when taken out in 1887 . Fruit, small, only good in quality, of little value.

Dumelow (of Wisconsin).-Synonym, Dumelow's seedling. Six trees were planted. Fruit was borne in 1876,1878 , and 1879 and fair crops in 1884,1886 , and 1888 . One tree died previous to 1884 , one tree in 1885 , and the others were in good condition when taken out in I889. Fruit, large, round, greenish yellow with little red, very acid. An excellent cooking apple, but of little other value. Early winter.

Dumelow's SEedLING.-Same as Dumelow of Wisconsin.

Dunlap's sweEt.-One tree was planted under this name. It bore a few apples in $\mathrm{IS79}$, and the tree died between $\mathrm{I} 880$ and $\mathrm{I} 884$. The fruit was acid and was considered worthless.

DURABLE KEEPER.-Two trees were planted under this name, one of which proved incorrect. The variety is credited with bearing fair crops in 1878,1879 , and 1886 , and a few apples in 1884 . It was at one time considered worthy of further trial, but was taken out in 1887 as not of sufficient value. The fruit was of medium size, striped, nearly covered with red, sweet. Winter.

Dutch Mignonne.-Four trees were planted. The trees bore some in 1879 and again in 1884 a fair crop. Two of the trees had died previous to 1884 and the others were almost dead when taken out in $\mathbf{1 8 8 7}$. The fruit was large, good in quality, subacid, striped red. Winter. It was considered worthy of further attention in 1879 .

EARLY BELlFLower.-Two trees were planted. These bore a few apples in 1877 and the trees died between the years 1880 and 1884 . Fruit was of medium size, striped, oblate conic, subacid, very good in quality. Autumn.

EARLY HARVEST.-Three trees of this variety were planted without name and others under the name of Yellow Fune. These produced a few apples in 1878 , I879 and I 884 and a fair crop in I886. All the trees were either dead or were taken out by 1887 . The fruit is one of the worst among apples to scab, and it was only the last year that there was perfect fruit. Not worthy of a place here.

EARLY RIPE,-Two trees were planted. One of these died previous to 1884. The variety bore a few apples in 1872 and there is no further record of its bearing until I886, though it must, unquestionably, have borne in the meantime. There was a heavy crop in 1888 , and light crop in $1889,1890,1891$, and 1894 . This tree was taken out after the latter date. Fruit, very similar in appearance and season to the Early Harvest and much more free from scab. It is not productive enough here, however, to be of much value.

Ellivill's LATE. - Three trees were planted. These bore a few apples in 1877 . Sometime between this date and 1884 all the trees died. Fruit, of medium size, striped, sour, of very goorl quality. Winter.

ENGLish RUSSET (of western N. Y.) - Three trees were planted under this name which proved to be the Roxbury russet. See under Marietta russet.

ENGLISH RUSSET (of England).-Five trees were planted under this name but the fruit is different from anything described by American authorities under the name of English russet. The variety bore a few apples in $1878,1879,1891$, and 1894 , a fair crop in 1886 and a good crop in 1888 . Fruit, large, roundish conical, with little or no basin, russet, regular rich subacid of high quality. Winter. The trees seemed perfectly hardy and healthy when taken out in I\$95-6.

Fall Harvey.-Two trees were planted; one of these died previous to 1884 ; the other bore a few apples that season and was dead in 1886 . 
FALL ORANGE.-One tree was planted. This bore a few apples in 1878 , I879, I889, I89o, and I893, a fair crop in I886, I894, and I895, and full crops in I884 and ISSS. Fruit, medium to large, light yellow, rather mild subacid, excellent for cooking. September and October. Tree still remains in good health.

FALL STRIPE.-Two trees were planted. One of the trees died previous to ISS, and the other in I885. The variety bore a few apples in I8S8 and I889, and a fair crup in $188_{4}$. Fruit, large, nearly covered with red.

FAMEUsE.-One tree was planted, and it died between I 880 and 1884 without having fruited. The same variety in another orchard has done better but still seems undesirable for planting here, though it has done well in many places.

FARLEY's RED.-Two trees were planted. It bore one full crop in 1876 and was then girdled by mice and killed. Late winter.

FAY'S RUSSET.-One tree planted. A few apples were borne in 1878 and a light crop in $I \$ 79$ and the tree died between I8So and IS84. Fruit, small, yellow covered with russet, of very good quality.

FEDERAL.-Four trees were planted. A few apples were borne in 1878 and IS79 and a fair crop in 1884 . The trees were nearly dead at the latter date and were taken out in $\mathrm{I}^{8} \mathrm{~S}_{5}$. Fruit, medium, roundish, striped red, of very good quality.

FINK.-Four trees were planted in two different parts of the orchard. A light crop was borne in 1877 . All the trees were dead previous to 1884 . Fruit, of medium size, of very good quality, and a good keeper.

Fisk's FAll seedling.-Synonym, Fisk's seedling. Two trees were planted. A few apples were borne in 1878 and a light crop in 1879 . The trees died between 1880 and 1884 . Fruit, of medium size, red striped, mild subacid. Winter. Good in quality.

Fleiner. - Two trees were planted. One tree died in I 886 and the other was taken out in $1895-6$. They bore a few apples in $1878, \mathbf{I} 879, \mathbf{I} 886$, and I895, and a fair crop in I88s and $\mathrm{I} 894$. Fruit, small to medium, yellow, subacid, of a peculiar flavor, only good in quality. Fall. Of no value.

Forsythe's SEedling.-Two trees were planted. Only one of these fruited and this proved to be Late strawberry.

Forster SWEeT.--One tree was planted. This bore one poor fruit in 1876 and died soon after.

Foster's BEST.-Synonym of Pennock.

FOURTH OF JULY.-One tree was planted. It bore a few apples in I 884 and I 886 , I888, IS89, I890, and I894 and a small crop in I895. The tree seemed in perfect condition when taken out in I895-6. Fruit, of medium size, Russian, roundish conical, regular, pale yellow with a few red stripes, sharp subacid, very good to best for cooking. Summer.

FRANKLIN.- Three trees were planted. One tree died previous to $\mathrm{I} 884$, and another in $I 88_{5}$; the other was in fair condition when taken out in I895-6. A few apples were borne in I886, I889, I894, and I 895 and a fair crop in I888. Fruit, below medium, striped light red, subacid, only good in quality. Fall. Of no special value.

Franklin's JUNE.-Five trees were planted. Bore a few small to medium sized apples in 1879 . All the trees were dead previous to I884.

Fulton.-Two trees were planted under this name which were not true. The variety was found growing in another part of the orchard where it had been planted without name. It was doing well, bearing fairly regular and good crops.

FULTON STRAWBERRY.-Two trees were planted in different parts of the orchard. One died in 1885 and the other was taken out in IS95-6. The latter tree bore light crops in I888, I894 and I895. It was not considered to be productive enough to be of value. 
GARDEN ROYAL.-Three trees were planted. One of the trees died previous to 1884 and another in 1885 ; the other bore a few apples in 1886 and was taken out the next year as of no value.

GARDNER's SwAAR.-(Seems to be the same as Swaar). One tree was planted. It bore a few apples in 1886,1894 , and 1895 and a small crop in 1888 . Fruit, of medium size, roundish oblate, yellow, with occasional bronze blush, subacid, very rich. Early winter.

Geneva PIPPIn.-Two trees were planted. One tree died previous to IS84 and the other, though nearly dead, bore a few small, poor apples that season.

GENTLE'S LARGE SEED.-Three trees were planted. Two of these died previous to 1884 and the other bore a few apples in 1879 and $188_{3}$, a fair crop in 1884 , and a good crop in 1886 . It was taken out the next year because in poor condition. Fruit, medium large, oblate, sour, striped, of very good quality. Early winter. It was considered promising in 1879 .

Germanite.--Synonym of Farminite.

GEWISS GOOD.-Two trees were planted. One of them died previous to 1884 , the other bore a few apples in 1880 , and a fair crop of very small fruit in 1884 . It was dead the next year and was never considered promising.

GiLPIN.-See Small red long keeper.

GoLD APPLE.-T To trees were planted under this name. The trees proved to be of different varieties, one of which was probably from the stock. The other bore a few apples in 1877 and seems to have died soon after. Fruit, large, light crimson color, subacid. Fall.

Golden APPLE. - Two trees were planted. These bore a few apples in 1878 and 1879, but both died previous to 1884. Fruit, medium to large, of very good quality.

Golden BALL.-Six trees, from different sources, were planted. Four of these died without fruiting; another bore a few apples in 1884 and then died, while the last one bore a few apples in $1884, I 886,1891,1894$, and 1895 and a fair crop in I888. It was taken out in 1895-6. Fruit, large to very large, roundish oblate, yellow, sometimes shaded dull red, subacid, coarse, good for cookıng. September. Not productive enough.

Golden pearmain.-Downing says, synonym of Clarke pearmain. Two trees were planted. Both were in poor condition in 1884 . They bore a fair crop that year. One of them lived to bear a fair crop in 1886 and was cut out the next year. Fruit, small, only good in quality.

GOLDEN SWEET.--Seven trees were planted under this name in three different parts of the orchard, and two more which proved to be the same in another place under the name of Lalle. Four of these trees died previous to or soon after I884. The others were large healthy trees; two have been taken out, and the others still stand. These bore fair crops in $1884,1886,1888$, I890, and 1895 and have borne a few apples in I889, I89I, and I894. Fruit, of medium size or above, light yellow, sweet and rich. August. A popular variety but has not borne so much as it should to be valuable.

Golden winter. - Three trees were planted. The variety bore a few apples in I 878 and 1879 and all were dead previous to I884. Fruit, small, only good in quality, oblate, russet. Winter.

GoOSEBERRY.-Three trees were planted. One died the next year, the other bore a few apples in $1878, I 879, I 889, I 890,1893, I 894$, and 1895 and fair crops in 1886 and 1888. The trees were nearly dead when taken out in IS95-6. Fruit, large, roundish, yellow, subacid, pleasant, only good in quality. Not of much value.

Granny SPICE.-Two trees were planted. These bore fruit in 1877 and 1856 and the trees were taken out in $\mathbf{1} 887$. Fruit, of medium size, round, yellow, subacid. A ugust. Very good in quality. 
GRANTHAM.-Synonym of Fefferies.-Two trees of this variety were planted under this name and another under the name of fersey sweet. The variety bore a few apples in $1877,1878,1879,1890,1891$, and 1893 , fair crops in 1890,1894 , and 1895 , and a full crop in 1888 . One of the trees died between 1880 and 1884 , another was taken out in I89I, and the other still stands. Fruit, of medium size, oblate, striped red, with yellowish Alush, tender, mild subacid, pleasant, best in quality for either dessert or kitchen. August and September.

Gravenstein.-Five trees were planted. All but two of these died without fruiting and another died in 1887 . The variety bore a few apples in $1886,1888,1890$, I 894 , and 1895 . Fruit, of medium size, striped and marked red, subacid, very good to best in quality. September. Not valuable because not productive enough.

GREAT KEEPER.-Three trees were planted and at least one tree was not true. The trees bore a few apples in 1878,1879 , and 1884 . One of the trees died previous to 1884 and the others in 1885 .

GREEN's CHOICE.-Three trees were planted under this name. The variety bore a few apples in $1878,1879,1890$, and 1894 and full crops in 1884,1886 , and 1888 . Two of the trees died prior to 1884 and the other was taken out in 1894 .

GREEN LIMBERTWIG,-See Limbertwig, p. 329.

GREeN SKIN (of Virginia).-Four trees were planted. Three of these died previous to 1884 , the other bore a fair crop in 1888 and a few apples in I890 and 1894 and was then cut out. Fruit, of medium size, oblate, greenish yellow, subacid, very good in quality, but apt to scab and very inferior in appearance.

GREen Winter sWeET.-Two trees were planted under this name. The trees bore fair crops in 1878 and 1879 and were dead before 1884 . Fruit, small to medium size, red. Autumn. Only good in quality.

GREIST'S FINE WINTER.-One tree was planted. It bore a fair crop in 1877 and a few apples in 1878 and 1879 and the tree was dead before 1884 . Fruit, medium to large, red striped, oblate, of very good quality. Winter.

GREY APPLE.-Two trees were planted. These bore a few apples in $\mathrm{I} 88_{4}$ and I886. One tree liad died in 1884 ; the other died in 1887 . Fruit, of medium size and only good in quality.

GREY HOUSE. - Two trees were planted. One of these died in 1887 and the other was taken out in 1895-6. A few apples were borne in I884, I886, I894, and I895, and a full crop in 1888 . Fruit, of medium size, oblate, oblique, greenish yellow, splashed red, subacid, only good in quality. Season, late winter.

GRey VAndFVERE.-Synonym of Vandevere. One tree was planted. It bore a few apples in I878, I879, I884, I886, I890, I894, and I895, and a full crop in 1888 . Fruit, medium size, oblate, red striped, subacid, very good in quality. The tree always seemed in perfect health, but not productive enough.

Grimes' Golden.-One tree was planted. It bore fair crops in 1884 and I886, a full crop in I888, and a few apples in $1890,1891,1893$, and 1894 . The tree was then cut out. The fruit on this individual tree would not at any time have attracted attention for special excellence or the tree for fruitfulness; yet the variety is deservedly popular over a wide area as an early winter apple. Fruit, above medium, yellow, mild, and very pleasant subacid, one of the best in quality. Late fall and early winter, though with care it may be had until March.

Grosse Pigeonnette (?).-Two trees were planted. One died in 1887 and the other was taken out in $1895-6$. The variety bore a few apples in $1878,1879,1886$, and 1895 , and a full crop in 1888 . In 1878 the fruit was said to be "of little worth" and the next year "very good, worth trial." It is not now considered of any value. Fruit, medium to large, roundish, almost covered with red, harsh subacid, only good in quality, very showy. 
Gros vert (GRosse verte).-Six trees were planted. Two trees died in I885, and the rest, in poor condition, were taken out in 1887 . The variety bore a few apples in 1877 and 1884 , fair crops in 1878 and 1886 , and a full crop in 1879 . Fruit, large, green, acid, only good in quality. Early winter.

HALLOCK'S FAVORITE.-Two trees were planted and both died between 1879 and 1884. They bore a few apples in 1878 and 1879 . Fruit, small, only good in quality.

HANCOCK.-One tree was planted which still remains in good condition. It bore a few apples in $1884,1886,1890,1891$, and 1895 , and a full crop in 1888 . Fruit, rather large, roundish oblate, oblique, greenish yellow, splashed dull red; dots, very conspicuous. Flesh, coarse, yellowish, subacid, good in quality. December to April.

HARRISON.-Two trees were planted. One tree died in 1885 and the other was in fair condition when taken out in $1895-6$. The variety bore a few apples in 1878,1879 , 1884, I886, I89I, I894, and I895, and a full crop in I888. Fruit, small, yellow, acid, juicy, only good in quality. A noted cider apple in some places.

HARVEST RED STREAK.-Six trees were planted, three under this name, two under the name of Philadelphia queen and one under the name of Bullock's pippin. All were sound and healthy when taken out in $1895-6$. The variety bore a few apples in 1893 , fair crops in $1886,1890,1894$, and 1895 , and a full crop in 1888 . Trees large and irregular. Fruit, medium size, roundish conical, splashed red, with a thin bloom, subacid, good in quality. Last of July and first of August. It is apt to be imperfect and irregular in size.

HIESTER. - Three trees were planted in two different parts of the orchard. One tree died previous to 1884 , another in 1885 and the third was in fair condition when taken out in $1895-6$. The variety bore a few apples in $1877,1878,1879,1894$, and 1895 , a fair crop in 1888 , and a good crop in 1886 . Fruit, medium to large, roundish, striped light red, good in quality, mild subacid. Late fall and early winter.

HENWOOD.-Two trees were planted. One died previous to 1884 and the other was in fair condition when taken out in $1894-5$. A few apples were borne in 1878,1879 , 1886 , and 1894 , and fair crops in 1879 and 1888 . Fruit, of medium size, roundish oblong, yellow, blushed dull red, brisk pleasant subacid, very good in quality. Not productive enough.

HENWOOD BELLFLOWER. - Four trees of two different varieties were planted under this name. The variety (?) bore some apples in $1 S_{77}$ and all the trees were dead previous to 1884 .

HEPLER. - Two trees were planted. One of these died previous to 1884 and the other was in good condition when taken out in 1895-6. The variety bore a few apples in $1878,1879,1884,1890,1893,1894$, and 1895 , a fair crop in 1886 , and a full crop in 1888. Fruit, of medium size or above, oblate, yellow, blushed pale red, brisk subacid, very good quality. Late winter. This variety at one time seemed very promising.

HERR's wiNTER. - Two trees were planted in different parts of the orchard. One died in 1885 , the other bore a few apples in 1886 and was taken out in 1587.

Hess.-One tree was planted. It bore a few apples in 1878,1879 , and 1884 , and good crops in 1886 and 1888 . The tree was in good condition when taken out in 1894. Fruit, of medium size, roundish, striped, acid, only good in quality.

Hicks (Buckram).-Four trees of this variety were planted in different parts of the orchard under the names Hicks, Buckram, and Bentley sweet. All the trees were in poor condition in 1884 and I 886 and three of them were taken out in I887. The other tree seemed to recover largely and is still a very fair tree. The variety has no record of bearing until 1884. One tree bore a few apples that year and two others full crops, and all the trees bore fair crops in 1886 . The tree still left bore a few apples in 1889 and 1893 , fair crops in 1890 , I891, and I894, and full crops in I888 and I895. Fruit, large, somewhat irregular, striped red, sweet, very good to best. Season, latter part of July and first part of August. It is good to eat when less than half grown. 
Higby sweEt, - Nine trees were planted under this name. Two of these did not fruit and two others proved to be a sour russet winter apple, while the rest were true. Both trees and fruit are too liable to scab. A few apples were borne in 1878 , I879, I 891 , and 1894 , fair crops in $1884, \mathrm{I} 886$, and 1895 , and a full crop in I888. Fruit of medium size, roundish conic, pale yellow with clear pale red blush, spicy sweet, very good or best when perfect. Late fall and early winter.

Hightop winter siveet.-Two trees were planted. A few apples were borne in 1886 and 1895 and a small crop in 1888 . The trees were in good health when taken out in $1895-6$. Fruit, small, greenish yellow, sweetish, tough. November and December.

Hill's FAvorite.-One tree was planted. This bore a few apples in I886, a small crop in 1888 , a fair crop in 1895 . The tree was in good condition when taken out in I $595-6$. Fruit, below medium size, oblate, rich yellow marbled with red, subacid, good to very good. September.

Hill's LONG STEM.-Two trees were planted. A few apples were borne in I886, I89I, I894, and I 895 , and a fair crop in 1888 . The trees were in good health when taken out in IS95-6. Fruit, below medium size, round, greenish yellow, almost sweet. Latter half of August.

Hinckley's sweet. - Five trees were planted. Three trees died previous to I884. The other two, in poor condition, bore a few apples that year and died the next. Fruit, large, good in quality

HysLo CRAB.-One tree was planted under this name which proved not to be true. The variety was found growing in another place where it had been planted without name. While this is usually recommended as one of the best of the Siberian crabs, it has not done well in this orchard.

HobBs' LATE sweEt.-Four trees were planted under this name. At least one of these was a small, sour, worthless apple. The sweet apple seems to have borne a few apples in 1878 and 1879 , and a fair crop in 1884 . All either died or were cut out previous to ISS8. The sweet apple was medium to large, yellow, roundish, good to very good in quality.

HOLLAND'S RED WINTER.-Three trees of two varieties under this name were planted. There is a record of a full crop in 1877 and a few apples in 1878 , 1879, and I884. Two of the trees died previous to 1884 and the other in 1885. Holland's red winter is given as a synonym of Winesap, and in 1887 the fruit was voted as being very much like Winesap, but with whiter flesh.

Hollis RED.-Same as Holly.

Holly.-Six trees were planted and at least one tree was not true to name. The variety bore apples in $1879,1884,1886$, and 1895 , and a heavy crop in 1888 . Fruit, small, roundish, striped, almost covered with red, sweetish. Quality, good, and keeps until the following summer.

HoRning. - Synonym of Sops of wine. The variety bore a fair crop in 1884 , good crops in 1886 and 1888 , and some fruit in $1878,1879,1889$, I89o, and 1891 . The trees were taken out in $189 \mathrm{I}-2$. Fruit, of medium size, roundish, striped, and nearly covered with red, subacid. Quality, good. Season, August. While the trees seem to bear well enough and the variety is often recommended, it does not seem desirable on account of inferior quality.

Honey GREENing.--Two trees were planted. The variety bore a few apples in 1878,1879 , and 1886 . One tree died previous to 1884 and the other was taken out in 1887. Fruit, medium size, yellow, sweet, good to very good. Early winter.

Hooker. - Three trees were planted under this name. A few apples were borne in 1876 . Two of the trees died previous to 1884 and the other in 1885 with no further record of fruiting. Fruit, small, conical, truncate, yellow with russet patches, and striped dull crimson. Season, winter. 
Hoops.-One tree was planted. This tree bore small crops in 1888 and 1895. Downing gives Hoops as a synonym of Greyhouse, but.as grown here the two have not been identical, though similar.

HopkINS RED.-One tree was planted. It bore some fruit but died 'between ISSo and ISS4. Fruit, oblate, sour, striped red.

Hormead pearmain.-Two trees were planted. These bore a few apples in 1878,1879 , and 1886 , and were cut out in 1888 . Fruit, large, oblate, yellow, subacid, sprightly, good to very good in quality. Early winter.

Horse APPLE. - Two trees were planted. One was taken out in 1890 , and the other in 1895-6. The variety bore a fair crop in 1886 and 1883 and a few apples in I89I, I894, and I895. Fruit, above medium size, round, rich yellow, shaded with orange red, subacid, rich, but not pleasant, in season during August.

Housum's RED.-Three trees were planted. One died in 1879 , another previous to 1884 , and the third was taken out in 1889 . The variety bore in 1878 and 1879 . Fruit, of medium size, and very good in quality.

HubBardston.-Synonym of Hubbardston nonsuch. Four trees were planted. One tree died soon after 1873 and all the rest previous to 1884 . A few apples were borne in 1878 and 1879 . Fruit, large and of very good quality.

Hughes' Virginia crab.-Synonym of Hewes' Virginia crab. Four trees were planted under this name and another under the name of Waugh's crab. The trees were all in perfect health when taken out in I894-5. They bore a few apples in I886 and a fair crop in 1888 and I894. Fruit, small, yellowish, and dull red, acid, good only for cider.

HULSE's SWEET.-One tree was planted. It bore a few apples in 1886, I89I, and I 894 and full crops in I888 and I895. Fruit, small, oblate, pale yellow, sweet, only good in quality.

HUNGE. - Two trees were planted. One tree died in 1885 and the other was in fair condition when taken out in $1895-6$. The variety bore a few apples in I884, I886, I 894 , and I 95 and a fair crop in I888. Fruit, large, roundish oblate, yellow, mild subacid, not rich, only good in quality.

HUNT'S RUSSET. - Three trees were planted in two different parts of the orchard. They bore fair crops in 1878 and 1879 and all were dead before I884. Fruit, small, russet, very good in quality. Season, January to April.

HurLbut.-One tree was planted which was in good health when taken out in I $895^{-6}$. It bore small crops in I888, I894, and I 995 . Fruit, medium size, roundish oblate, greenish yellow, striped with red, mild subacid, only good in quality.

HyatT's wonderful. - Two trees of two different varieties were planted under this name. One of these has not been determined with certainty, but seems to be Clyde beauty. The other is the same as was planted in other parts of the orchard under the names Gloria mundi, Pound pippin, Fosephine, and Mountain belle. The variety under all these names has been a shy bearer. Three of the trees were in good condition when taken out in $1895-6$, but none of them had ever borne more than a fair crop. Fruit, very large, oblate, yellow, subacid, only good in quality. Only valuable as a curiosity on account of its large size.

HyatT's wonderful (Clyde beauty?).-Tree very large and healthy. There is no way of separating the record of this tree from the others until I 888 , in which year it bore a very heavy crop, -28 bushels. There were a few apples in I859, I89I, I893, and a fair crop in 1895 .

ILLINOIS RED. - Five trees were planted under this name, and there were two different varieties. The Illinois red bore 2 few apples in 1878 and 1879 and all were dead before 1884. Fruit, medium size, red, only good in quality. Season, September.

IMPERIAL MAGNIFIQUE.-Two trees were planted. One tree was dead previous to 
1884 , and the other was taken out in 1889. A few apples were borne in 1878,1879 , I884, and I886. Fruit, large, oblate, sour, striped. Season, winter. Quality, very good.

INDIANA FAVORITE.-This variety was found growing under the name of Green szueet. It bore a few apples in $1879,1884,1891$, and 1894 , a fair crop in 1886 , and heavy crops in I888 and IS95. Fruit, medium size, oblate, splashed with red, pleasant subacid, very good in quality. Season, late winter. This is an exceedingly promising variety, reminding one of Minkler, but has been much more productive.

IRISH PEACH.-One tree was planted. It bore fair crops in 1886 and 1895 , a full crop in I885, and a few apples in I89I and I894. Fruit, below medium size, roundish, splashed with light red, mild subacid. Quality, good. Season, August.

ISLE of IVIGHT PIPPIN.-Two trees were planted. These bore a fair crop in 1886 and 1838 and a few apples in 1891 and 1894 . Then the trees were taken out. Fruit, small, oblate, yellow, rich subacid. Season, early winter. Too small to be of value and not productive enough.

JACKson.-See Amos Fackson, p. 3 I3.

JACOB APPLE. - Two trees were planted. One tree died in 1885 and the other was nearly dead when taken out in 1887 . It bore full crops in 1877 and 1886 , and a few apples in 1884. Fruit, roundish, oblong, pale yellow, subacid, but not rich. Season, autumn.

James Coal. - Two trees were planted. One died previous to 1884 , and the other in 1885 . The trees fruited but once, and were then considered promising. Fruit, medium size, roundish, sweet, striped. Season, late fall.

JAMES River.-According to Downing this is a synonym of Willow twig, but while there is some reseniblance both in tree and fruit as grown here, they cannot be said to be identical. Fames River is also given as a synonym of Limbertwig, but our Fames River was very different from that. Three trees were planted. One died previous to 1884 , another in 1885 , and the third was in good condition when taken out in I895-6. The variety bore a few apples in 1878,1879 , and 1884 , fair crops in 1886 and I895, and a full crop in 1888 . Much of the fruit is apt to be imperfectly matured. The fruit differs from Willow in being smoother, paler in color, and in having lighter colored flesh of milder quality.

JANE.-Two trees were planted. One died previous to 1884 and the other was in good health when taken out in $1895-6$. The trees bore some fruit in 1880,1884 , and

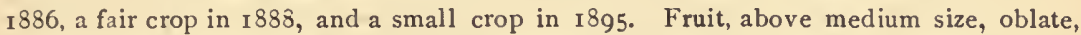
lemon yellow, marbled pale red, rich, mild subacid, very good in quality. Season, winter.

JANET (of Muir).-One tree planted under this name proved to be the same as Bastard or Wright's fanet. The tree was sound when taken out in $1895-6$, but was unproductive.

JARMINE BALLARD.- Two trees were planted under this name and two more under the name of Farminite. One tree died previous to $188_{4}$, another in 1887 , and the other two were good trees when taken out in $1895-6$. The variety bore a few apples in 1878 , $1879, \mathbf{I} 884, \mathbf{1 8 8 6}, \mathbf{I} 89 \mathrm{I}$, and $\mathbf{I} 894$, a fair crop in $\mathbf{I} 888$, and a small crop in 1895 . Fruit, medium size, oblate, greenısh yellow, striped red, subacid, mild, only good in quality.

JERSEY BLACK.-One tree was planted. It bore a full crop of fruit in 1877 , and seems to have died soon after. Fruit, small, but very good in quality.

JERSEY SWEET.-Four trees were planted under this name. One proved to be Fefferies, another Lowell, and a third a green sweet apple, which was not identified.

JEFFERIES.-See Grantham.

JEWETT'S BEST. - Two trees were planted. One of these died previous to I884, and the other was in fair condition when taken out in 1889 . The variety bore a few apples in $1878,1879,1884$, and 1886 , and a fair crop in 1888. Fruit, large, oblate, nearly covered red, very good in quality. Seasou, winter. 
JEWETT'S FINE RED.-Two trees were planted. The trees bore a few apples in I884, at which time they were in very poor condition. Both were dead in I886. Fruit, very small, only good in quality.

JOHN STUART'S RED.-Three trees were planted, one of which bore a greenish yellow sweet apple, and the other small red, subacid. Fruit, only good in quality

JoHnson's FINE WINTFR.-Synonym of York Imperial.-Two trees were planted. Both trees were taken out in 1887 , because nearly dead. They bore a fair crop in 1877 and a few apples in 1884 and 1886 . Fruit, medium to large, oblong, subacid, striped with red, of good quality. This variety has done well in many places, but not in this orchard.

Jonathan (oF BUler).-One tree was planted under this name. The fruit is very distinct from fonathan. The tree has always been in good health. It bore a few apples in $1878,1879,1889,1891$, and 1893 , fair crops in 1886,1894 , and 1895 , and a heavy crop in 1888 . Fruit, rather large, oblate, striped red, pleasant, subacid, very good in quality. Season, September and October.

JoNes'S EARLY HARVEST.-Synonym of Carolina red Fune.-Two trees were planted under this name, which proved to be the same as Carolina red Fune. mundi.

Josephine.-Synonym of Belle Fosephine. Proved to be the same as Gloria

JUNALUSKEE.-Two trees were planted under this name. One of them appeared to be true, the other not. The trees were in good health, when taken out in 1894-5. Fruit, small, red, subacid, very good. Season, winter. Not of much value.

JUNE APPLE.-Synonym of Carolina red Fune. Four trees were planted unde: this name and two under the name of Fones's early harvest. The variety seems not to have borne until I886. Since then it has borne two fair crops, and a few apples four times. The fruit is very apt to scab. Fruit, small, oblong, red, subacid, pleasant, very good in quality. More profitable south.

KIDDLESTON PIPPIN.-Two trees were planted. One died in 1887 and the other was nearly dead when taken out in 1889 . The variety bore fair crops in 1878 and 1879 and good crops in 1886 and 1888 . Fruit, small to medium size, oblong, sour, yellow or russet. Quality, very good. Season, early winter.

KENTUCKY LONG KEEPER.-One tree was planted. It bore a few apples in $1 S_{7} 8$ and 1879 and then died. It seemed to be the same as Krauser's pippin.

KENTUCKY RED.-Synonym of Kentucky red streak. Two trees were planted. One of these died previous to 1884 . The other bore a few apples in 1886 , I889, and I $89 \mathrm{I}$ and a small crop in I888. Fruit, small, roundish, conical, striped red, mild subacid, almost sweet. Season, January to April.

KENTISH FILL-BASKET.-Two trees were planted, one of which was not true to name. Fruit, large, roundish oblate, yellow shaded dull red, subacid, only good. Fall apple.

KING OF PIPPINS (KING OF THE PIPPINS?).-One tree was planted. It bore a full crop in 1877 and a few apples in 1878 and 1879 . The tree died in 1885. Fruit, medium to large, oblate, yellowsh shaded red, good to very good in quality.

King's POCKET.-Two trees were planted. One died previous to I 884 and the other was in fair health when taken out in 1894-5. The variety bore a few apples in I877, I889, and I89o, and good crops in 1886 and 1888 . Fruit, large, roundish, oblate, yellow, usually shaded dull red, mild, subacid, scarcely good. Season, September and October.

KINGSLEY.-One tree was planted. It bore a fair crop in I884 and died in I887. Fruit, medium size, roundish, acid, striped with red, good in quality.

KRAUSER PIPPIN (KRAUSER ?).-Two trees were planted. They bore a few apples in 1878 and 1884 and a fair crop in 1879 . All the trees died before 1886 . 
LADY APPLE. - Two trees of this variety were grown under the name of Wax apple. The variety bore a few apples in 1886 and full crops in 1888 and 1895 . One tree was in poor condition and was taken out in 1889. The other is in good health. Fruit, small, oblate, yellow blushed red, very handsome, subacid, pleasant, quality very good. Season, late winter.

LADY CRAB.-Four trees were planted under this name, all of which proved to be Lady Elgin. The trees bore heavy crops in 1877,1878 , and 1879 , a good crop in 1886 , a fair crop in 1888 , and a few apples in $1889,1890,1891$, and 1893 . The trees were then all taken out, though in good condition.

LADIES' SWEET.-Two trees were planted under this name, one of which was not true. The tree never bore more than a few apples and died in 1887 . Fruit, large, best in quality.

LAlle.-Same as Golden sweet.

LANCASTER GReEning; LanCaster (of Ind.).-Seem to be the same. Three trees were planted. These bore more or less fruit for different seasons up to 1886 . The last of the trees died in 1887 . Fruit, medium size, conic, subacid, good to very good in quality. Season, late winter.

LANCASTER (of Jones).--1s different from the other, being oblate, a sharper acid, richer. Season, September and October.

LARGE FINE RED.-Two trees of two varieties were planted under this name. One was a pale yellow apple of very good quality, ripe in August, and the other was oblate, irregular, yellow, shaded with red, subacid. Only good in quality. Season, winter.

LARge NeVEr FAIL. - Two trees were planted. One died previous to 1884 , and the other in 1887 . The latter bore a few apples in 1886 .

LARGE RAMBo.-Synonym of Western beauty. Two trees were planted. They bore a few apples in 1878 and 1879 and both died previous to 1884 . Fruit, large and very good in quality.

LARGE Yellow Siberian CRAB.-Two trees of this variety were found growing under other names. Fruit, very large for a crab, clear waxen yellow, subacid, pleasant, best in quality for either kitchen or dessert. Season, August. The trees have borne a few apples in 1890 and 1892 , fair crops in $1884,1886,1889$, and 1893 , and full crops in I885, I89I, I894, and I895. It probably bore some earlier than this, but there is no record of it. One of the best, if not the best, of the Siberian crabs.

LATE STRAWBERry. - One tree was planted under this name; another which proved the same thing under the name of Forsythe's seedling, and two others without name. This tree bore large crops in 1878 and 1888 , fair crops in $1879,1884,1886,1894$, and 1895 , and a few apples in 1889,1890 , and 1893 . Fruit, medium size, roundish oblong, greenish yellow, splashed with red, pleasant subacid, very good in quality. Season, September. This seems to be a very desirable variety.

LAWVER'S SEEDLING No. I.-Bore a few apples in 1878 and 1879 , and died soon after. Fruit, medium size, yellow with a blush, of very good quality. Season, August.

LEDGE sweET.-Two trees were planted under this name. The fruit was large, subacid, ripe in September.

LEICESTER SWEET.-One tree was planted. It hore a few apples in I 884 and I886, and was nearly dead when taken out in 1887 . The fruit was large and of very good quality.

Liberty.-One tree was planted. This bore a few apples in $1878,1879,1886$, $1889,1890,1891$, and 1894 and a full crop in 1888 . The tree was taken out in $1894-5$. Fruit, large, roundish, shaded and striped dull red, sweetish. Quality, good. Season, winter.

Limbertwig, 8 trees; Limbertwig (of King), 5 trees; Limbertwig (of Mathias), 16 trees; Green Limbertwig, 2 trees; Oilo Limbertwig, 3 trees; Robey's Limber- 
TWIG, 3 trees; ReD Limbertwig, 3 trees.-Two trees planted as Orange red, and two others as Red jewel (of Ky.), proved to be Limbertwig. Most of the trees planted under the names Limbertwig, Limbertwig (of Mathias), and Ohio limbertwig grew tall and erect, compact, and bore a few apples of very inferior quality, apparently of Russian origin. At least two of the trees planted as Limbertwig proved to be Summer limbertwig. There is some difference in color of the fruit of Green limbertwig and Red limbertwig, as would be indicated by the names, though not so much as the names would lead one to expect. All the trees known to have been Limbertwig remained in good condition until taken out. Fruit, medium size or below, roundish oblate, skin rough greenish yellow, shaded and striped dull red, mild subacid, quality good. Season, late winter. The variety fruited in $1878,1879,1884,1886,1888,1889,1891,1894$, and 1895 , yielding fair or full crops at least four times.

Lindenwald. - Two trees were planted. One died in 1885 and the other was taken out in $1895-6$. The variety bore a few apples in 1886,1888 , and 1895 . Fruit, medium size or above, roundish, lemon yellow, subacid, very good in quality. Season, September.

London.-Two trees were planted. One of these died soon after and the other was taken out in $1895-6$. It bore a few apples in $1886,1859,1891,1894$, and 1895 and a fair crop in 1888 . F ruit, large, roundish, greenish yellow, subacid, good to very good in quality. Season, November to January.

LoNDON PIPPIN.-Three trees were planted and•all were dead by 1886 . The variety bore a few apples in 1879 and 1884 . Fruit, medium size, only good in quality.

LoNDon sweEt.-One tree was planted. It bore a few apples in 1884, 1886, $\mathrm{I} 889, \mathrm{I} 89 \mathrm{I}, \mathrm{I} 894$, and $\mathrm{I} 895$, and a fair crop in 1888 . Fruit, medium to large, roundish oblate, yellow, pleasant sweet, good in quality. The tree was in good health when taken out in $1895-6$.

LONG STEM (of Conn.).-Two trees were planted. Both were in fine condition when taken out in $1895-6$. The trees bore a few apples in $1877,1878,1879,1886,1891$, and 1894 , a full crop in 1888 , and a fair crop in 1895 . Fruit, below medium size, roundish oblate, yellow, very sweet, pleasant, good in quality. Season, September to November.

LONG STEM (of Jones).-T wo trees were planted and both died previous to I884. A few apples were borne in 1878 and 1879 . Fruit, small to medium, good in quality, striped red.

LOWELl.-One tree was planted under the name of Fersey sweet. The tree bore a few apples in $1886,1889,1890,1891$, and 1894 , fair crops in 1884 and 1895 , and a full crop in 1888 . Fruit, large, roundish, oblong, yellow, rich, pleasant subacid, very good or almost best in quality. Season, last of August and first of September.

McCoy's PIPPIN.--Two trees were planted. Both were dead previous to 1884 . They bore a few apples in 1877,1878 , and 1879 . Fruit, large, greenish, good in quality. Season, fall.

McDowell's sweEt.-Two trees were planted under this name. One proved to be Gloria mundi and the other was not identified.

MCLEAN'S WINTER PIPPIN.-One tree was planted. It died between I880 and I 884 , having borne fruit in 1878 and 1879 . Fruit, small, roundish, red, only good in quality. Season, winter.

MCLellan.-Three trees were planted. Two of these were dead in 1884 and the other was reported as in only fair condition in 1886 , but it has since recovered and is now in very good health. It has borne a few apples in $1878,1879,1889$, I 891 , and 1893, fair crops in 1884 and 1886 , and full crops in $1888,1890,1894$, and 1895 . Fruit, large, roundish, nearly covered with red, rich, subacid. Season, October to December. The fruit is more like Downing's description of Ohio nonpareil than McLellan. One of our best and most productive fall apples.

Magnolia.-Three trees were planted. They bore a few apples in 1878,1879 , 
I888, and 1895 . The trees were all in good health when taken out from 1894 to 1896 . Fruit, medium size, oblate, striped red, subacid, aromatic. Season, October.

MAGNUM BONUM.-Four trees were planted under this name; all proved to be mangum.

MAIDEN APPLE. - Two trees were planted under this name, one of which proved untrue. The variety bore a few apples in 1878 and 1879 . Fruit, small, of very good quality. Season, autumn.

MAiden's BLUSH.-This was planted under the name of Uchella. A little fruit was borne in $1877,1878,1879,1884,1890,1893$, and 1894 , and fair crops in 1886 and 1888. Fruit, large, oblate, yellow with a red blush, sharp subacid, very good in quality. Season, autumn. Though this is one of the most popular of our fall apples it has not done well in either orchard where planted on the Experiment Station farm.

MAIDEN'S FAVORITE.-One tree was planted under this name, which proved to be the same as Mangum.

Mammoth JUnE.--Four trees were planted. Two of the trees were taken out in 1887 , because nearly dead, and another in 1893 . The fourth tree was still in good health when taken out in $1895-6$. Fruit, medum to large in size, roundish, conic, shaded and striped red, pleasant subacid. Season, last of July and August.

Mangum.-One tree was planted under this name, at least one under the name of Magnum bonum, and one under the name of Maiden's favorite. The variety fruited in $I 878, I 879, \mathbf{I} 884$, and $I 886$, bore a few apples in $I 889, \mathbf{I} 89 \mathrm{I}$, and 1893 , fair crops in 1890 and 1894 , and full crops in 1888 and 1895 . Fruit, small to medium, roundish conical, greenish yellow, striped red with a bloom, pleasant subacid, very good in quality. Season, autumn.

Mannington.- Three trees were planted. One of them proved to be Red Astrachan.

Mannington's pearmain,-One tree was planted and it died between 1879 and 1884. It bore a fetw apples in 1877,1878 , and I889. Fruit, medium size, considerably russet, very good in quality. Season, early winter.

MANSFIFLD RUSSET.-Three trees were planted. One tree died in 1886 , but the other two are in good health still. They bore a few apples in $1878,1886,1889$, and 1892 and full crops in $1877, I 884, I 888, I 890, I 891, I 894$, and 1895 . Fruit, small to quite small, roundish or oblong, thinly russet, shaded with red, rich subacid, very good in quality. Season, November and December. Too small for general purposes.

MARCH'S RED SEEDLING. - Two trees were planted under this name, one of which proved untrue. The variety bore fruit in $1876,1878,1879,1884, I 886,1888,1891$, 1894 , and 1895 , and only one even fair crop in that time. Fruit, medium size, roundish, oblate, red over most of the surface, pleasant subacid, very good in quality. Season. October to January.

MARIETTA RUSSET.-Synonym of Roxbury russet, and was the same as English russet of Western N.Y. Altogether six trees were planted. The variety bore a few apples in $1878,1879,1884,1886,1889,1891$, and 1894 , and a fair crop in 1838 . The trees were in good condition when taken out in 1894-5. Fruit, medium size, oblate, russet, subacid, very good in quality. Season, late winter.

MARIETTA SEEK-NO-FURTHER. - Two trees were planted. One tree was dead in 1884 , and the other died in 1886 . It bore a fair crop in 1877 and 1879 and a few apples in 1878 and 1884 . Fruit, medium size, oblate, striped, subacid, very good in quality. Season, late fall and early winter.

Marshall (of Maine).-One tree was planted. It bore some fruit in 1876 and died between $\mathrm{I} 880$ and 1884 . Fruit, large, sour, striped, very good in quality.

Marshall's sweet.-One tree was planted. It bore a few apples in 1876,1878 , and 1879 , and was dead in 1884 . Fruit, small to medium, oblate, sweet, very good in quality. Winter. 
MARYLAND BEAUTY.-Synonym, Maryland red streak. Two trees planted under the former name, died soon after without fruiting. Three trees were planted under the latter name. They bore a few apples in $1878,1889,1891$, and 1894 , fair crops in 1877 , I886, I888, I890, and I895. Fruit, of medium size, roundish, marbled and splashed with red, subacid, not rich, only good in quality. October.

MARY MAYer. - Two trees were planted under this name. They bore fruit in 1876,1880 , and 1884 . One seems not to have been true, the other was small, oblate, greenish yellow, striped dull red, subacid, only good in quality. Winter.

MASSAC PIPPIN.-Fifteen trees were planted under this name. One of these proved to be Pennock, another Summer pound royal, and another the same as one of the Sheepnoses. The rest died without being identified.

MAVERICK SWEET.-Three trees were planted. The trees bore some in I884, I886, a full crop in 1888 , a few apples in 1890,1894 , and the trees were in very poor shape when taken out in 1894-5. Fruit, below medium, roundish oblate, greenish yellow, shaded and striped with dull red, pleasant sweet, only good in quality. November to February.

MAY.-One tree was planted. This bore a few apples in 1884 , and was dead in 1886.

MAY (of Adair). Five trees were planted under this name. They bore a few apples, three different times. The fruit was of medium size, poor in quality. August and September.

MAY QUEEN.-One tree was planted. It bore apples three times, and the tree was in fair condition when taken out $1892-3$. Fruit, medium size, oblate, nearly covered with red, of very good quality. September.

Melon.-One tree was planted. It bore no fruit until 1884 and at that time the tree was nearly dead. It died the next year.

Michael Henry pippin.-Two trees were planted. The variety bore a few apples in $1878,1879,1889,1891$, and 1893 , a fair crop in 1886 , and full crops in 1877 and 1888. The trees were in poor condition when taken out 1893-4. Fruit, medium size, conical, yellow, very good to best. Winter.

MidDle.-One tree was planted under this name. It bore some fruit once, but was dead in 1879 . Of little value.

Milam.-One tree was planted. This bore a few apples in 1878 and 1879 , and was dead previous to 1884 . This is one of the varieties that was standard thirty to forty years ago, but has been generally superseded.

Minister. - Two trees were planted. One tree died in 1885 and the other in 1890. The variety bore fair crops in $1878,1879,1884,1886$, and a full crop in 1888 . Fruit, medium to large, roundish, cblong, conic, striped red, subacid, good in quality. Late fall and early winter.

Minkler.-See Brandyzine, under which name the variety was planted.

MississipPI RED.-Three trees were planted under this name. One proved to be Red Astrachan, another was a medium sized yellow apple, ripe in August, and the other left no record of fruiting.

MisSOURI KEEPER.-Two trees were planted under this name. One died in 1887 , and the other was taken out in 1893 . The trees bore a few apples in 1877,1878 , and 1884 , fair crops in 1879 and 1886 , and a heavy crop in 1888 . Fruit, medium size or below, striped red, subacid, only good in quality.

MoNARCH.-One tree was planted. It bore a few apples in 1836 and again in 1888 . The tree was taken out in I89o. Fruit, medium size, roundish, oblate, striped red, subacid, only good in quality. September.

Monk's FAVoRite.-One tree was planted. It bore a few apples in 1877,1878 , and 1879 , and a fair crop in 1886 . The tree was nearly dead when taken out in 1887 . Fruit, large, oblate, subacid, of very good quality. Winter. Rotted badly on the tree. 
Montalivet.-Two trees were planted under this name. One proved incorrect and the other, though apparently true, was a very inferior fruit under our conditions. The trees only bore a few apples in 1884 . One tree died in 1886 and the other in 1887.

MOORE'S SWEETING.-Two trees were planted under this name, and seven others under the name of Red sweet pippin. These proved to be Moore's sweet. One of these trees died in 1885 and another in 1887 . Two of the trees were taken out in 1889 , and the other five in $1894-5$. There is some difference in the bearing of the individual trees. In general they produced a heavy crop in 1577 , fair crops in 1878,1879 , and 1886 , a few apples in $1884,1888,1889$, and 1891 . Fruit, large, oblate, striped dull red, sweet, only good in quality.

MOREY'S MELON.-One tree was planted under this name. It is very different from Melon. The tree bore a few apples in 1878, 1886, 1889, 1891, 1894, and 1895 and fair crops in 1884 and 1888 . Fruit, small, roundish, oblate pale yellow, mild, subacid, rich, very good in quality. September

MOTE'S RED SEEDLING.-Three trees were planted under this name. All the trees were dead previous to 1886 . They bore a few apples in 1879 and 1884 . One of these proved to be Mote's sweet, and another was unknown and of no value.

MoTHer. - Two trees were planted. One of these died in 1885 and the other, nearly dead, was taken out in 1889 . The variety bore a good crop in 1886 , and a fair crop in I 888 . Not productive enough here to be of value.

Mother Davis.-One tree was planted. It produced a few apples in 1878 and 1879 , and the tree died previous to 1886 . Fruit, small to medium size, of very good quality. November.

Mountain belle. - One tree was planted. The tree bore a few apples in i 884 and 1886 and was deaci in 1887 . Fruit, large, oblate, striped, only good in quality. Winter.

Mountain SPRout.-One tree was planted under this name. It bore fruit once ancl was dead previous to $188_{4}$. The fruit was sweet, but of no value.

MUNSon's SWEET.-One tree was planted. It bore a few apples in 1877 and 1886 and a fair crop in 1884 . The tree died in 1887 . The fruit is medium to large, oblate, yellow, sweet, good in quality. Autumn.

MURPhy's RED.-Six trees were planted. Some fruit was borne in $188_{4}$ and a good crop in 1886 . Four of these trees were dead in 188.4 , another died in 1885 , and the last in 1887 . The fruit was of very little value.

NeASLEY Bellflower.-Synonym, Neisley bellflower. Two trees were planted. This variety bore a few apples in $1879,1884,1886,1890,1891$, and 1894 , and a fair crop in 1888 and 1895 . The trees were in tair condition when taken out in 1895-6. Fruit, rather large, roundish oblate, striped dull red, rich subacid, very good in quality. Early winter.

NED.-Synonym of Saylor. Three trees were planted under this name, three under the name of Creek, and two others under the name of Custard. The trees seem to be almost perfect in health and hardiness. This variety bore a few apples in 1877 , $1873,1879,1884,1891,1892$, and 1893 , fair crops in 1889.1891 , and 1894 , and full crops in 1886,$1888 ; 1890$, and 1895 . Fruit, medium or above in size, roundish oblate, greenish yellow, mostly covered with red, pleasant subacid, good to very good in quality. November to January, or later, if well cared for. All things considered this has been our best early winter apple on the Experiment Station farm.

Nelson's victory.-Two trees were planted. One tree died previous to 188.4 and the other was taken out in 1887 . A few apples were borne in 1886 . Fruit, large, oblate, striped dull red, subacid, only good in quality. Late autumn.

NEWARK KING.-Two trees were planted in different parts of the orchard. One died soon after and the other was in very fair condition when taken out in $1895-6$. The 
tree bore a few apples in $1886, \mathrm{I} 894$, and I 595 , and full crops in 1884 and $\mathrm{I} 888$. Fruit, above medium size, roundish or oblong, striped bluish red, brisk subacid, very good to best. November to January.

New Hampshire sweEt.-One tree was planted. The tree bore some fruit in $I 878$, a few apples in $I 889, I 89 I$, and $I 894$, fair crops in $I 886, I 890$, and $I 895$, and a full crop in 1888 . The tree was in excellent condition when taken out in $1895^{-6}$. Fruit, large, roundish, yellow, slightly russet, rich, sweet, very good in quality. September. This is one of the more valuable fall sweet apples.

NickajACK.-Two trees were planted. One died soon after. A few apples were borne in 1886 , and the tree bore no more fruit. It was in good condition when taken out in I 890 .

Nine partners. - Two trees were planted and both died previous to 1884 . The variety bore a few apples in 1878 and 1879 .

NiX's LARGE RED STREAK.-One tree was planted under this name. It bore some fruit in 1884 and was dead in I886. Fruit, small, yellow, of no value.

North Carolina RED, - Two trees were planted. One died in 1885 and the other was taken out in 1887 . The variety bore a few apples in 1878 and 1879 . Fruit, of medium size, oblate, dark red, mild subacid, good in quality. Winter.

NotTingham BRown.-Two trees were planted in different parts of the orchard. The variety bore fair crops in 1878 and 1879 , and both trees were dead previous to 1888 . Fruit, large, conical, russet, rich, mild subacid, very good in quality. September and October.

Numbers 55, I06, AND IO8 (of Morrison).-These were planted, but none of thrm seemed worthy of special mention.

OBLONG CRAB.-Three trees were planted under this name, all of which bore small oblate crabs of excellent quality, but too small to be of value.

Оніо LIMBERTWIG.-See Limbertwig.

OHIO RED CHEEK.- Two trees were planted. These bore a few apples in 1878 and 1879 and were dead in 1884 . Fruit, large, red striped, good in quality. Winter.

ORANGE RED proved to be Limbertwig.

ORTLEy.-One tree was found that had been planted under the name of Red Detroit. Some fruit was borne in 1886 , and small crops in I888, I889, I891, I894, and I895. The tree was not in good condition when taken out in $1895-6$. Fruit, medium size, oblong conic, greenish yellow, brisk subacid, very good in quality. Early winter.

ORNAMENT DE TABLE.-T To trees were planted under this name, and two others which proved to be the same thing under the name of Osceola. The latter name was not correct. The variety bore a few apples in $1878,1879, \mathbf{I} 884$, and 1886 , and a fair crop in 1888 , and a few apples again in 1891,1894 , and 1895 . Fruit, roundish, oblate, almost covered with red, pleasant subacid, almost sweet, very good in quality. October to December.

OSBORN'S PIPPIN.-One tree was planted. It bore a full crop in 1879 and was dead in I89o. Fruit, yellow, acid, very good. Winter.

Osceola.-Two trees were planted not true. See Ornament de tabie.

OsKaloosa.--One tree was planted. It was in fair condition when taken out in r895-6. It bore a few apples in $1878,1879,1884,1886,1891,1894$, and 1895 , and a fair crop in 1888 . Fruit, medium size, oblate, yellow, subacid, only good in quality. October and November.

Ox sweET.-One tree was planted. It bore a few apples in 1878,1879 , I889, $\mathbf{r} 890$, and 1893 , fair crops in $1884,1886,1891,1894$, and 1895 , and a full crop in 1888 . The tree was in almost perfect condition when taken out in I895-6. Fruit, large, oblate, greenish yellow, sweet, good to very good. September to November. This has been a very good fall sweet apple and would be profitable for the kind and season. 
PARAdise STRIE D'Hiver.-One tree was planted under this name. It bore a few apples in $1878,1879,1884,1886,1889,1890,1894$, and 1895 , and a fair crop in 1888. The tree was in fair condition when taken out in $1895^{-6}$. Fruit, medium to large, oblate, shaded and striped red, brisk subacid, very good in quality. September.

PARMENTIER REINETTE.-Two trees were planted. One died in 1872 and the other in 1887 . The variety bore a few apples in 1879 and 1384 , and a fair crop in 1886. Fruit, medium size, roundish, nearly covered with red, subacid, very good in quality.

PAULET RUSSET-Two trees were planted and both were in good condition when taken out in 1889 . The trees bore a few apples once. Fruit, small, yellow, subacid, of little value. August.

PAWPAW-Two trees were planted. They bore a few apples in 1884 and were dead in 1886.

PEACH-Synonyms, Peach of Kentucky, Winter peach. Seven trees were planted. All but two of the trees had died previous to 1888 . Those two are at present in fair condition. The variety bore a few apples in $1876,1878,1879,1884,1891$, and 1894 , fair crops in I 886 and 1895 , and a full crop in 1888 . Fruit, above medium size, oblate, light waxen yellow, sprightly subacid, very good in quality. November to January.

PEACH POUND SWEeT.-One tree was planted. It bore a few apples in 1878 and I879, and died between 1880 and I884. Fruit, medium to large in size, sweet, very good in quality. Winter.

PEAK'S RED, or PEAK'S RED WINTER.-Two trees were planted under each name, but all proved to be the same. The variety bore a few apples in 1884 and 1886 , and all the trees were dead in $\mathbf{1} 888$. Fruit, large, red, subacid, only good in quality. Winter.

Pearmain Rouge D'Hiver. - Three trees were planted, at least one of which was incorrect. Fruit, small, roundish, conical, russet, with a red cheek, sprightly, subacid, of very good quality. Late winter. The variety was always a shy bearer.

PECK's PLeasant.-Two trees were planted in different parts of the orchard. One tree died in 1879 , and the other previous to 1884 . The variety bore a few apples in 1878 , and a light crop in 1879 . Fruit, rather large, roundish, yellow with a blush, sprightly subacid, very good in quality. Through winter.

PEDRICK's MULberRY,-Two trees were planted. One tree died previous to 1884 , and the other in 1888 . The variety bore a few apples in $1877,1878,1879$, I886. Fruit, variable in size, of very good quality. Winter.

Pekin (of Indiana).-One tree was planted. It bore a few apples in 1879 and I886, and a full crop in 1884 , and was dead in 1887 . Fruit, medium to large, oblong, blushed red, subacid, very good in quality. Winter.

PenNock.-Was found growing under the names Pennock of Crain, Crooked red, Foster's best, and Massac pippin. The variety bore a few apples in 1878 , I879, 1886, IS89, I 890 , I89I, and I894, a fair crop in 1884 and I895, and a full crop in I888. Fruit, rather large, oblate, usually oblique, red, coarse, subacid, only good in quality. Through winter.

People's CHOICE.-One tree was planted and it is still in very fair condition. It has borne a few apples in $1878,1879,1889,1890,1893$, and 1894 , fair crops in 1884,1886 , and $\mathrm{I} 895$, and a full crop in 1888 . Fruit, of medium size, roundish, conic, mottled red, rich, brisk subacid, very good in quality. October and November.

Perpetuelle.-One tree was planted. It bore a full crop in 1877 and was dead previous to I884. Fruit, medium size, conical, yellow with a blush, subacid. Winter.

Philadelphia green.-Two trees planted under this name proved to be Harvest red streak.

Phillip's sweEt.-One tree was planted. It bore a few apples in 1886 and was dead in 1888.

PICKARD'S RESERve. - Two trees were planted. One died previous to 1884 and 
the other was taken out in $1894-5$. It bore a few apples in 1877,1879, IS86, I89I, and I894, and a small crop in I888. Fruit, large, oblate conic, yellow shaded dull red, rich, subacid, very good in quality. December to April.

PICKMAN.-One tree was planted which remained in good condition until taken out in 1895-6. It bore a few apples in 1878, I879, I894, and I895, and a fair crop in 1886 and I888. Fruit, medium to large, oblate, yellow, rich, sprightly subacid, very good to best in quality. November to February.

PIFER.-One tree was planted. It bore a few apples in $1878,1879,1884$, and I886, and a fair crop in 1888. The tree was in fair health when taken out in 1892 . Fruit, of medium size, roundish oblate, greenish yellow, striped red, subacid, only good in quality. Late winter.

PIGEON BLANC.-Three trees were planted in two different parts of the orchard. The trees bore a few apples in $1878,1879,1884$, and 1886 , and all were dead in 1888 . Fruit, medium to large, oblate, yellow, subacid, only good in quality. Late fall.

Pigeonette Jerusalem.-Three trees were planted. These bore fair crops in I 878 and I879, and all were dead before I884. Fruit, small, oblong, striped, flesh very white, very good in quality, subacid.

PINE APPLE RUSSET,-Three trees were planted under this name. The fruit proved to be red striped and not russet. All the trees were dead before 1886 .

Pleasant valley Pippin.-One tree was planted under this name but it proved to be Pomme grise.

Poeschell's sweet.-Two trees were planted. These bore a few apples in 1877 but were dead in I884. Fruit, large, yellow, oblate, sweet, only good in quality. Winter.

POMME GRISE D'OR.-Synonym of Pomme grise. The variety bore a full crop in IS 72 , a few apples in I886, a fair crop in 1888 , and a few apples again in I889, IS9I, and IS94. The tree was taken out in $1894-5$. Fruit, small, oblate, russet, subacid, very good to best in quality. Early winter.

POPLAR BLUFF.-Synunym of Smith's cider.

PORTER APPLE.-Two trees were planted. They bore a few apples in 1878 and a light crop in 1879 . Both trees were dead in $188_{4}$. Fruit, large, roundish, cblong. yellow, subacid, very good to best in quality. Autumn.

POUND PIPPIN.-Four trees were planted under this name. 'Two of them bore large red striped apples and the other proved to be the same as Gloria mundi.

Pound Royal.-Six trees were planted under this name. Only one lived to fruit and it proved to be the same as Summer pound royal.

President Ewing.-Two trees were planted. The variety bore a few very small, poor apples in 1854 and both trees were dead in 1886 .

PRICE (of South Carolina),-Two trees were planted. A few inferior apples were borne in 1884 . One tree was dead in 1886 and the other died in $\mathrm{ISS}_{7}$.

PRIESTLY.-Two trees were planted under this name which proved to be Striped gilliflozer.

PRIESTLY RUSSETTING.-One tree was planted. It bore a few apples in IS 75 and I579, and a fair crop in I886. The tree died in I887. Fruit of medium size, striped red and roughened with russet dots. Quality, very good. Winter.

Princely. - Two trees were planted. These bore a few apples in ISS + and ISS6. Cne tree died in ${ }^{188} 7$ and the other in 1888 .

Prince's yellow winTER.-One tree was planted. It boré a full crop in I $388_{4}$, a fair crop.in I886, and was dead in 1888 . Fruit of medium size, oblate, yellow, subacid, very good in quality. Winter.

Princeton.-Two trees were planted. One died in 1885 and the other in 1887 . The variety bore a few apples in 1884 and I886. Fruit of medium size, subacid, of very good quality. Autumn. 
Prize siveet.-Synonym of Premium. These bore a few apples in ISS 4 , ISS9, IS9I. IS94, and IS95, and fair crops in ISS6 and I8S8. The trees were in fair condition when taken out in $1{ }^{5} 95-6$. Fruit of medium size. roundish, yellow with red markings, sweet, only good in quality. Early autumn.

Prother's winter.-One tree was planted. It bore a few inferior apples in IS56 and was taken out in $\mathrm{ISS}_{7}$.

Pu: (Pomme?) WATER sweet.-Two trees were planted under this name. The fruit proved to be subacid.

QUEEN. - Three trees were planted. They bore an average crop in $188_{\boldsymbol{f}}$, and all were dead in 1886. Fruit of medium size, yellow, shaded red, subacid, very good in quality. Autumn.

Rambo.-Two trees were planted under this name and others as "resembling Buckingham." All the trees but one were dead by 1888 , and that was not in good condition and was taken out in $1893-4$. The variety bore fair crops in 1878 , I879, I886, and 1888 and a few apples in nearly every other year until taken out. Fruit of medium size, oblate, greenish yellow, striped dull red, subacid, very good in quality. This variety usually bears heavily and young, but the trees are short lived.

RaMbour Franc.-Synonym of Summer rambo. Four.trees were planted. Two of them had died previous to $\mathrm{ISS}_{4}$, and the others are still in first rate condition. The variety bore a few apples in $I S_{7} S_{1}, I S_{79}, I 8 S_{4}, I 889, I 89 I, I 893, I 894$, and I895, fair crops in $1 S_{77}$ and 1886 , and a full crop in ISSS. Fruit, large, roundish oblate, striped red, pleasant subacid, very good in quality. Late summer. The only possible objection to this variety is that it lacks a little in productiveness.

RAMSDELL'S RED SWEeT.-Synonym of English sweet. One tree was planted. This bore a few apples in 1878,1579 , and 1884 , and a fair crop in 1886 . The tree was dead in ISS8. Fruit of medium size, oblong conic, striped red, sweet, good in quality. Through autumn.

RARE RIPE.-One tree was planted. It bore a fair crop in 1884 , a full crop in IS86. and a few apples in I888. The tree was taken out in I889. Fruit, of medium size, oblate, subacid, yellow. Late winter. Not attractive, only good in quality.

RED AshMore.-Three trees were planted under this name. Proved to be Red Astrachan.

RED Astrachan.-Five trees were planted under this name and others under the names Captain, Carver (of New York), Compte d'Orloff, Deterding's early, Mannington, Red Ashmore, and Royal russet. The variety under all these names has been unpromising, not productive enough, and the fruit often cracking from the effects of a disease which so far as observed is peculiar to Red Astrachan and Fourth of Fuly, though much worse on the former.

RED CEDAR. - Two trees were planted and they proved to be of diflerent varieties, one a large russet and the other Red cedar. Small to medium, roundish, dark, rich red, good in quality. Winter. Both trees died previous to I884.

RED DETROIT.-Two trees were planted. One proved to be Ortley and the other died before fruiting

RED FALL PIPPIN.-Synonym of Red zuinter pearmain. Two trees were planted under this name, only one of which proved true.

RED JEWEL (of Kentucky). - Two trees were planted under this name, both of which proved to be Limbertwig.

RED OATS. - Two trees were planted under this name. The variety bore a few small apples in $1 \delta_{7} 6$, and the trees were dead soon after.

RED LIMBERTWIG.-See Limbertwig.

RED NEVER FAIL. - Synonym of Rawle's fanet. Four trees were planted, part of which proved not to be true to name. Three of the trees died previous to ISS 4 and the 
other was cut out in I889. Fruit, roundish, small to medium in size, greenish yellow, striped red, subacid, very good in quality. Through winter. Apt to overbear and is then too small for anything but cider.

RED PAWPAW.-Probably a synonym of Pawpaw. Two trees were planted. These bore a full crop in 1884 , a few apples in 1886 , and were taken out in 1890 without having fruited any more.

RED RANCE. - Three trees were planted. These bore a few apples in 1884 and 1890 , fair crops in 1886 and 1895 , and full crops in 1877 and 1888 . Fruit, of medium size, oblong, conic, nearly covered with rich dark red, numerous white dots, rich subacid, very good in quality. During winter.

RED Robinson.-Three trees were planted. 'Two of these died previous to 1884 and the other was dead in 1886 . The variety bore a few apples in 1878 and 1879 and a fair crop in 1884 . Fruit, oblate, of medium size, striped red, acid, good in quality. Winter.

RED RUSSET. - Two trees were planted under this name but all were dead previous to 1884 and none had fruited. Another tree, planted without name, was decided to be Red russet. This bore a full crop in 1888 , small crops in 1890 and 1895 , and a few apples in I889, I89I, and 1894. Fruit, rather large, roundish oblate, dark red with appearance of russet, subacid, very good in quality. Late winter and spring. Not productive enough to be of much value.

RED SEEK-NO-FURTHER. - Six trees were planted under this name. The trees were from different sources and were not alike. One lot bore small to medium fruit, red, subacid, pleasant, very good in quality. Early winter. The other lot bore fruit similar to the Westfield seek-no-further in most respects, scarcely so large and more red. Both varieties have been fairly productive but the former is too small to be of value. All the trees were in fair condition when taken out in $1894-5$ and $1895-6$.

Red Simmons.-Synonym of Simmons' red. Two trees were planted. One died in 1887 and the other was in good condition when taken out in $1895-6$. Fruit was borne in $1878,1879,1889,1891$, and 1894 , fair crops in 1886 and 1895 , and a heavy crop in 1888 . Fruit, below medium size, oblate, red, mild subacid, very good quality. Early winter.

RED STREAK WINTER.-Two trees were planted. These bore a few apples in I 886 and were taken out because nearly dead in 1888 .

RED STRIPE (of Pennsylvania).-Three trees planted under this name died without fruiting. The variety was found planted under the name of White Rawle's Fanet. The record does not show when it began bearing. There were full crops in 1886,1888 , 1890 , and 1895 , fair crops in 1889,1891 , and 1894 , and a few apples in 1893 . Fruit, of medium size, oblong conical, light yellow speckled and splashed light red, pleasant subacid, very good in quality. Middle of July to last of August. This would be one of the best summer apples for family use but does not ripen evenly enough for the commercial grower.

RED SWEET PIPPIN.-Synonym of Moore's sweet.

RED WINTER SWEET.-Two trees were planted. These bore a few apples in 1886 and were dead in 1887.

RED WARRIOR.-Synonym of Nickajack. Four trees were planted under this name. One proved to be Sweet Fanet, two others were not determined, and the fout th died without fruiting.

REFUGEE.-One tree planted under this name proved to be Winesap.

REINETTE DANiEL.-One tree was planted. It bore a few apples in 1878 and 1879 , and died in I885. Fruit, large, oblate, striped dull red, subacid, very good to best in quality. Winter. 
ReINeTTE DE LA CHine. - Two trees were planted. These bore a few apples in I 578 and 1879 and both died between I 884 and I 886 . Fruit, of medium size, russetted, sour, good in quality. Winter.

ReinetTE DE MADERE. - Three trees were planted. One died in 1885 and the other two in $1887-8$. The variety bore a few apples in 1878,1879 , and 1886 , and a good crop in 1872 . Fruit, large, yellow, often russet, subacid, very good to best in quality. Winter.

REINETTE DES REINETTES.-Five trees were planted. Three of the trees died previous to 1886 , one died in 1887 , and the other was in fair condition when taken out in I895-6. The variety bore a few apples in 1878,1886 . I889, I894, and 1895 , a light crop in 1879 , and a fair crop in 1888 . Fruit, medium to large, oblate or roundish oblate, striped dull red, subacid, good to very good in quality. Winter.

REINETTE DE THORN.-Two trees planted under this name proved to be Kentish pippin. One tree died in 1885 , and the other was in fair condition when taken out in $1895-6$. The variety bore a few apples in $1878,1889,1890,1894$, and 1895 , a light crop in 1879 , and fair crops in $\mathbf{1} 886$ and $\mathbf{1} 887$. Fruit, of medium size, roundish oblate, golden yellow, with some russet, rich brisk subacid, very good to best in quality. Through winter.

Reinette Dolbear.-Three trees were planted. They bore a few apples in 1878 and 1879. All were dead previous to 1884 . Fruit, large, russet, acid, scarcely good in quality. Winter.

REINETTE ElTE koNning (Reinette Edelkönig?). - Two trees were planted. One was dead in 1886 , and the other bore a fair crop that season and was dead before IS88.

REINETTE GRIS D'ANJOU.-Two trees planted bore a few apples in $1878,1879,1886$, I889, I890, I894, and I895 and a fair crop in I888. Fruit, of medium size, oblate, lemon yellow, rich subacid, very good in quality. September and October.

REINETTE SUISSE.-Synonym of Swiss reinette. Three trees were planted. These bore a few apples in 1878,1879 , and 1880 , and a fair crop in 1886 and all were dead before I 888 . Fruit, medium to large, oblate, yellow, only good in quality. Winter.

Relish.-Four trees were planted. The trees bore a few apples in $1878,1879, \mathbf{1} 886$. I 889 , I894, and I895, and full crops in $I 877$ and I888. Fruit, small to medium, oblate, nearly covered red, subacid, only good in quality. Season, autumn.

RibSTON PIPPIN.-Two trees were planted. These bore a few apples in 1878 and I879, and were dead in I886. Fruit, medium to large, more or less russetted, subacid, very good in quality. Winter.

RichmoND.-Four trees were planted. Two of these died in $187 \mathrm{I}$ and the others bore a few apples in 1878 and 1879 and were dead in 1885 . One of these last was considered true and very promising; the other was not true.

RIJMER.-Three trees were planted. These bore a few apples in 1878 and 1879 . and the trees were all dead previous to 1884 . Fruit, of medium size, oblate, subacirl, striped. Autumn

Robertson's PEARMaIn.-Synonym of Red winter pearmain. See Red fall pippin. ROBEY'S LIMBERTWIG.-Synonym of Limbertwig.

RoCK PIPPIN.-Two trees were planted under this name and another was found which had been planted without name. The trees bore a few apples in 1878 and 1879 , and fair crops in $1886, \mathrm{I} 888$, and $\mathrm{I} 894$. Fruit, medium size, oblong or roundish oblong, yellow blushed, subacid, firm, good in quality, will keep until August.

Royal Limbertwig. - Two trees were planted. One died in 1884 ; the other is still in excellent condition. The variety bore a few apples in 1884 , good crops in 1886 , 1888,1890 , and 1895 , and fair crops in 1889,1893 , and 1894 . This is quite distinct from the other limbertwigs though still, perhaps, showing a relationship in both tree and 
fruit. Fruit, above medium size, oblate, greenish yellow, marbled dull red, pleasant subacid, good to very good in quality. Late winter and spring.

Royal RUSSET.-Three trees were planted. At least two of these proved to be Red Astrachan, and the other did not fruit.

RUsset.-One tree was planted. This bore fruit in ISS+ and IS86 and died in I887. Fruit, late winter, russet, subacid.

RUSSET CIDER.-One tree was planted. It bore a few inferior apples in 1886 and was dead in 1888 .

RUSSET GREENING.-Three trees were planted. They bore a few apples in 1878 and $\mathrm{I} 879$ and all were dead in $\mathrm{I} 88_{4}$. Fruit, large, oblate, greenish, somewhat russet, subacid, very good in quality.

RUSTy COAT.-One tree was planted. It bore a few apples in 1878,1879 , and I 886 and was dead in I888. Fruit, of medium size, only good in quality.

SAlliE's sweet.- Two trees were planted. These bore a few apples in 1878 and 1879 and a full crop in 1888 and 1889 . The trees were in good health when taken out in I89o. Fruit, rather small, roundish conical, striped red, sweetish, only good in quality. Late fall and early winter.

SantovcheE.-Four trees were planted. Two of these died before I886, another bore a fair crop that season and all were dead before 1888. Of no value. Fruil too small and poor.

SCARLET GOLDEN PIPPIN.-Two trees were planted. One tree was dead in IS84. The other bore a fair crop of poor fruit in 1886 and was dead in IS88.

Schull.--One tree was planted. It bore a few inferior apples in 1886 and was taken out in $\mathrm{I} 888$.

SCHRODER's BLACK. - Three trees were planted. The trees bore a few apples in I884, I886, I889, I89I, I894, and I895 and a heavy crop in IS88. The trees were in first-rate condition when taken out in $1595-6$. Fruit, below medium in size, oblate, greenish, striped dull dark red, mild subacid, only good in quality. Last of winter and during spring.

SHREEve.-Synonym of Hannah. Four trees were planted under this name. The variety bore a few apples in I859, I890, and IS94 and fair crops in IS86 and I838. It was taken out in $1894-5$. Fruit, large, oblate, greenish yellow, splashed crimson, subacid, almost poor in quality. October to December.

SCRibner's Spitzenberg.-One tree was planted. It bore a few apples in 1878 and IS79. The tree died in 1885 . Fruit, of medium size, roundish oblate, nearly covered red, very good in quality. Winter.

SEEK-NO-FURTHER.-Synonym of Westfield seek-no-further. Three trees were planted. One tree was taken out in 1889 and the other two are in only fair condition at present. The variety has born a few apples in 1877, I 878 , I879, I886, I889, and I 893 and fair or full crops in $1888, \mathrm{I} 890, \mathrm{I} 89 \mathrm{I}, \mathrm{I} 894$, and I895. Fruit, medium or above in size, roundish conical, dull yellow, striped dull red, pleasant subacid, very good to best in quality. October to January. Valuable for late fall and early winter.

SELma.-One tree was planted. It bore a few apples in 1886 and was dead in $1890^{\circ}$.

SHAKER GREENING. -One tree was planted. It bore a few apples in $18_{77}, 1878$, and 1879 and fair crops in 1884 and 1886 . The tree was dead in I89o. Fruit, medium to large or small, with a full crop, oblate, yellow, subacid, only good in quality. Through winter.

Shannon.-Two trees were planted under this name and proved to be American pippin or Grindstone. The variety bore fair crops in 1886 and 1888 and a few apples in IS94 and I895. Fruit, of medium size, oblate, dull yellow, striped dull red, mild subacid, only good in quality. January to June.

ShARP APPLE.-Two trees were planted. The trees bore a few apples in 1878 , 
IS79. ISS7, IS89, and IS93 and good crops in I8S6, IS88, I890, I891, I894, and IS95. The trees are still in good health. Fruit, small to medium size, oblate, pale yellow, often blushed, very pleasant subacid, almost sweet, very good to best in quality. September and first of October.

SHARPE's sweET.-Same as Sharp apple.

SHARPE'S WINTER.-One tree was planted. It bore a few apples in IS79 and was lead in ISS4.

SHEEPNOSE and SHEEPNOSE (of Virginia).-Seven trees were planted under these names, of at least four varieties. One of the varieties proved to be Kentucky red streak, two of them were not determined, and the fourth seemed to be true. The Sheepnose bore a few apples in $1877,1856,1890$, and $1 \$ 94$ and fair crops in $1884, I S 88$, and IS95. Fruit above medium size, oblong conic, pale lemon yellow, mild subacid, very good in quality. Through winter.

SHEPPAKD'S SIVEET.-Two trees were planted. These bore a few apples in 1577 , $I_{8} 4$, and ISS6. One tree died in $I_{5} S_{5}$ and the other in 1887 . Fruit, roundish, small, sweet, striped, poor in quality.

SHIAIVASSE BEAUTY.-One tree was planted. It bore a few apples in IS73, IS89, and IS9o, fair crop in IS79, and full crop in ISSS. Fruit, above medium size, oblate, nearly covered with red, sprightly subacid, very good in quality. October and November. Too apt to be imperfect.

SHIPLEY GREENING.-One tree was planted. It bore some fruit in I879 and was dead in I834. Fruit, of medium size, conical, greenish, sweet, of very good quality.

Simmons' winter.-Four trees were planted. These bore a few apples in 1877 and again in 1884 . The first year the fruit was medium to large, very good in quality, and the last, small and poor. The only remaining tree at the latter date was nearly dead.

SLOAN"S SEEDLING,-One tree was planted. It produced a few apples in 1878 and IS79, a fair crop in IS84, and was dead in I886. Fruit, small, roundish, striped, subacid, very good in quality. Winter. Not of value.

SMALL RED LONG KEEPER.-Three trees planted under this name proved to be Gilpin. It bore good crops in $1878,1879, \mathbf{1} 854, \mathbf{1} 856$, and 1888 , and was taken out in IS92-3. Fruit, small to medium, roundish, red, subacid, almost sweet, very good in quality. Late winter and spring.

SMALL RED (of Purdy).-One tree was planted. It bore a few apples in 1886 and a few small crops aítcrwards. Fruit, quite small, oblate, red, sour. August. Of no value.

SMITH's CIDER.-Five trees. were planted under this name and one under the name Poplar Bluff. All were dead in IS56. The variety bore four fair crops. Fruit, medium to large, roundish oblate, striped red, subacid, pleasant, very good in quality. Early winter.

SOPS OF WINE.-See Hominy.

SOUTHERN PEARMAIN.-One tree was planted. It bore some fruit in IS77 and was dead in ISS6.

SOUTHERN wINTER. - Two trees were planted. These bore a few apples in IS77, fair crops in 1575,1879 , and 1886 , and a full crop in $15 S 8$. The trees were cut out in ISgI. Fruit, medium to large, roundish conic, greenish yellow, pleasant subacid, not rich, quality good to very good. Early winter. Use, cooking.

SPAFFORD RUSSET. - Two trees were planted. These bore a few apples in $\mathrm{I}_{77}$, I878, IS84. IS56, ISS9, IS9o, and I894, small crops in 1879 and $I 895$, and a full crop in IS85. The trees were in good condition when taken out in IS95-6. Fruit, small, oblate conic, russetted, mild subacid, only good in quality. Through winter.

SPARHAwk.-Two trees were planted. One was dead in 1884 , the other bore a few apples in ISS6 and was dead in 1888. 
SPICE RUSSET.-Two trees were planted under this name. 'One proved to be Summer pound royal and the other died without fruiting.

SPREADING BOUGir.-One tree was planted. It still stands in good health but has not fruited.

SPRINGHILL PIPPIN.-Two trees were planted. One died in 1870 and the other was in good condition when taken out in I839. Fruit, large, roundish, yellow with a blush, sweetish, only good in quality. Early winter.

SPRINGHill SpItZenberg.-Two trees were planted. These bore a few apples in 1878 and 1879 . One tree was dead in 1884 and the other died in 1885 . Fruit, medium to large, oblate, bronze color, subacid, very good in quality. Winter.

SPRINGPORT PIPPIN.-Synonym of Spring pippin. Two trees were planted under this name. These bore a good crop in 1879 . One died previous to 1884 and the other in 1885 . Fruit, sweet, very good. September.

SPRING swaAR. - Four trees were planted under this name. The fruit resembled Rhode Island greening. The trees bore a few apples in $1870,1879,188_{4}$, and 1886. One tree was dead in 1884 , two of the others died in 1887 , and the last in 1889 .

STEPHEnSON's winter.-Five trees were planted. The variety bore a fair crop in 1886. One tree was dead in 1879 , ancther in 1884 and three others previous to 1888 . The last was taken out in 1890 .

STREAKED PIPPIN.-Two trees were planted and both were in good condition when taken out in $1895-6$. They bore a few apples in $1878,1879,1884, \mathbf{1} 889$, I891, and I 894 and fair crops in $1886, \mathbf{1} 888$, and 1895 . Fruit, rather large, roundish, striped red, pleasant subacid, very good in quality. November and December.

STRIPED Gilliflower, - Two trees were planted under the name of Priestly. These were in good health when taken out in $1895-6$. The trees bore a few apples in I 886 and I895. Fruit, large, roundish, ribbed, pale yellow splashed with red, pleasant subacid, good in quality. September to November.

Sturmer Pippin.-Two trees were planted under this name. One died without fruiting and the other proved to be Large yellow Siberian crab.

STrx (of Coxe).-One tree was planted. It bore a few apples in $18_{7} 8$ and 1879 , and the tree was broken down and was taken out in 1887 . Fruit, of medium size, pale greenish, acid, only good. Winter.

SumMer bellFlower.-Three trees were planted under this name. The trees bore a few small winter apples in 1879 that were of no value. One tree was dead in 1884 and the others died in 1885 .

SUMMER POUND ROYAL. - Several trees were planted. The variety bore good crops in $1886,1888,1890,1894$, and 1895 and a few apples in $1889,1891,1893$. Fruit, above medium size, roundish conical, greenish yellow, mild, subacid, not rich, good to very good in quality. August. This has been a promising variety for several years.

SUMmer RAMBo.- Same as Rambour Franc.

SuMMER SEEK-NO-FURTHER.-Five trees were planted under this name in two different parts of the orchard. Only a part of the trees fruited anci such as did proved to be the same as Dumelow's seedling.

SUPERIOR EARLy. - Two trees were planted. One died the next year, the other proved to be Snow or Fameuse. It bore fruit in I884 and I886, and was dead in I 887.

SURPRISE.-One tree was planted. It bore a good crop of inferior fruit in 1886 and was dead in 1887 .

SutTon:-Two trees were planted under this name. These bore fruit in 1878 and 1879 and both were dead in 1884 . Fruit, above medium size, pale yellow with bronze blush, subacid, very good. August and September.

SwASEy. - One tree was planted under this name, but it proved to be Szeet bellfower of Wyandotie Co. 
SivEET BELLE ET BONNE.-Two trees were planted under this name and proved to be American pippin or Grindstone.

SWEET BELLfFLWER (of Pa.). - Same as Szeet bellflower of Wyandotte Co. There were three trees. The variety bore a few apples in $1884,1889,1891$, and 1893 , a fair crop in 1886 , and a full crops in $1888,1890,1894$, and 1895 . The trees are still in excellent condition. Fruit, large, roundish conic, russet, occasionally blushed, rich, sweet, very good in quality. September to last of November.

SWEET BELLFLOWER.-One tree was planted. It bore a few apples in I886, I889, I 891 , and I894, and fair crops in 1888 and 1895 . The tree was in fair condition when taken out I895-6. Fruit above medium size, roundish conical, angular, yellow, very mild subacid or sweet, very good in quality. Last of August and first of September.

SWEET CRAB.-One tree was planted under this name. It was a crab, but quite sour. The tree bore some fruit in 1879 and was dead in 1885 .

SwEET DOCTOR.-One tree was planted. This bore a few apples in 1878 and 1879 and was dead soon after. Fruit, large, roundish oblate, striped red, sweet, good in quality. October.

SWEET JANET.-Three trees were planted, one under this name, one as Red warrior, and the other as Turner. The variety bore a few apples in $188_{4}, 1886,1888$, I891, and fair crops in 1892,1894 , and 1895 . Fruit, large, almost round, striped, and nearly covered with red, sweet, not rich, good to very good in quality. October and November. The tree has the late blooming habit of Rawle's Fanet.

SwEeT PIPPIN.-Two trees were planted. These bore a few apples in 1877 and again in 1884 , and the trees were dead in 1886. Fruit, small, roundish, yellow, sweet, only good in quality. Late fall.

SWEet VANDERVERE.-Two trees were planted. These bore fair crops in 1878 and 1879 , and a few apples in 1884 , and were taken out because nearly dead in 1885 . Fruit, medium size, oblate, striped red, sweet, good in quality. Early winter.

Taunton.-Two trees were planted. These bore a few apples in 1877 . One was dead in $188_{4}$ and the other died in $188_{5}-6$. Fruit, above medium size, oblate, striped red, subacid, good in quality.

TAYLOR'S HARVEST.-One tree was planted. It bore a few apples in 1878,1879 , I 890 , and 1893 , a fair crop in I886, and full crops in 1888, I891, I894, and 1895 . Fruit, medium to large, roundish oblate, pale yellow, subacid, good to very good for kitchen. August. The tree is still in excellent health.

TEubner's CiDer.-Two trees were planted. These bure a few apples in 1877 , 1878,1879 , and 1886 . One tree was dead in 1886 and the other died in 1887 .

TEXAN RED.-One tree planted under this name proved to be an unknown small crab, the same as the one planted as Oblong crab.

THORNBERRY.-One tree was planted. It bore a few apples in 1878 and 1895 and a light crop in 1879 . Fruit, above medium size, oblate, yellow with a blush, subacid, very good in quality. Winter. The tree is in fair condition still.

Tinmouth sweEt.-Not a sweet apple. The proper name is Tinmouth. Two trees were planted. One died in 1887 and the other was in good condition when taken out in 1895-6. Fruit, medium size, oblate conic, lemon yellow, often blushed, brisk subacid, good in quality. Through winter.

TRADER'S FANCY.-Four trees were planted in two different parts of the orchard. The variety bore a few apples in $1878,1884,1886, \mathrm{I} 889, \mathrm{I} 890, \mathrm{I} 89 \mathrm{I}, \mathrm{I} 894, \mathrm{I} 895$, and fair crops in 1879 and 1888 . One tree was dead in 1884 , another in 1886 , a third in 1883 , and the fourth was in fair condition when taken out in $1595-6$.

TRADER'S RED.-One tree was planted. It bore a few apples in 1877 and 1879 . and the tree was dead in 1884 . Fruit, medium size, oblate, greenish, very good in quality. iate winter. 
Triumphant.-Two trees were planted under this name, one of which proved not true. The variety was an abundant bearer of fine crabs, but was exceedingly liable to blight. Fruit, rather large for a crab, roundish, nearly covered with red. August.

TuFTs. - Three trees were planted. These bore a few apples in $1877,1878,1879$, $\mathbf{I} 886, \mathbf{I} 889, \mathbf{I} 890, \mathbf{I} 894$, and $\mathbf{I} 895$, and a fair crop in $\mathbf{I} 888$. All the trees were in fair condition when taken out in $1895-6$. Fruit, rather large, roundish oblate, striped and shaded red, pleasant rich subacid, very good in quality. Autumn.

TulpeHocken.-Synonym of Fallawater. One tree was planted under this name and two others without name. The trees bore a few apples in 1884,1889, I890, I89I, 1894 , and fair crops in 1886 and 1888 . The trees were in poor condition when taken out. Fruit, large, roundish, greenish with a blush, mild subacid, good in quality. Late fall and early winter.

TURner's SEEDLING.-Two trees were planted under this name. One died without fruiting and the other proved to be Sweet fanet.

TURN OFF LANE. - Three trees were planted, one without name. All the trees were in good health when taken out. Fruit, small to medium size, oblate conic, striped red, pleasant subacid, very good in quality. Through winter. The variety has borne a few apples four times and fair crops three times.

Tuscaloosa.-One tree was planted. It bore a few apples in 1878 and 1879 , and a fair crop in I886, and was dead in 1887 . Fruit, large, striped red, subacid, poor to good in quality. Winter.

UCHELlA.-Three trees were planted under this name and proved to be Maiden's blush.

ULLOA.-One tree was planted. It bore a few apples in 1878 and 1879 , a fair crop in 1886 , and was dead in 1888 . Fruit, small, red, sweet, of very good quality. August and September.

UNION and UNION CRAB.-One tree of each was planted. It is a native crab (Pyrus coronaria) only a little larger than the average. The trees were very productive.

UTTER.-Two trees were planted. These bore a few apples in $1877, \mathrm{I} 878$, 1879 , $\mathbf{I} 859, \mathbf{I} 89 \mathrm{I}$, and $\mathrm{I} 894$, fair crops in $188+$ and $\mathrm{I} 890$, and full crops in $1886, \mathrm{I} 888$, and 1895 . The trees are still in good health. Fruit, medium to large, roundish or oblate conic, striped red, pleasant subacid, very good in quality. September and October.

VAUGHAN's WinTER.-Two trees were planted. These bore a few apples in 1878 and 1879 , and were dead in 1886 . Fruit, of medium size, good to very good in quality. Late winter.

VERMONT BEAUTY.-Two trees were planted. One died without fruiting and the other proved to be Large yellow Siberian irab.

Victuals.-One tree was planted. It bore a few apples in 1878 and 1879 , and was dead in 1884 . Fruit, large, oblate conic, yellow, sweet, very good in quality. September and October.

Virginia JUly.-Five trees were planted. These bore a few apples in 1878 and IS79. Four of the trees were dead in I884, and the other died in I885. Fruit, large, oblate, yellow, subacid, very good in quality. September.

VIRGINIA RED PIPPIN (Virginia pippin?).-Two trees were planted under this name. One proved to be a subacid, and the other sweet.

VIRGINIA RED STREAK.-Three trees were planted. These bore a few apples in 1878 and 1879 , and all were dead in 1884 . Fruit, medium size, oblate, marbled red with russet, subacid, very good in quality. Winter.

WALKUP SEEDLING. - Three trees were planted. These bore a few apples in 1878 , I879, and IS93, a fair crop in I886, and full crops in IS88, I889, IS9I, I894, and IS95. One tree was dead in 1884 and the other two were in good health when taken out in I $995-6$. Fruit, small, roundish oblong, yellow, subacid, aromatic, only good in quality. August. Not of value. 
Waltham ABBEY.-Three trees were planted. One of these proved to be the same as Walkup seedling. The variety bore a few apples in $1 S 78$ and 1879 . All the trees were deall in 1884 . Fruit, large, sweetish, very good in quality. September.

WARD'S LATE SEEK-NO-FURTHER.-One tree was planted. It bore a few apples in IS86. The tree was taken out in 1887 . Fruit, only good in quality. Not attractive and not valuable.

WATER (of Penn.).-Two trees were planted. One was dead in 1884 , but the other is still in good condition. This tree bore fair crops in $1886,1890,1891,1894$, and I 895, a full crop in I888, and a few apples in 1887, I889, and 1893. Fruit, large, roundish, striped red, pleasant subacid, very good in quality. September.

WAX APPLE. - Two trees planted under this name proved to be Lady apple.

WELLFORD'S VELLOW.-One tree was planted under this name. It bore small crops in 1889 , IS9o, and 1895 , and a few apples in 1889 and 1894 . The fruit does not answer to Downing's description of Wellford's yellow, but answers very well to Menonisten reinette. Fruit, medium size, oblate conic, light yellow, marbled dull red in sun, brisk subacid, rich, very good in quality. November to January.

IVells (of Ohio).-Synonym of Dominie. Two trees were planted. A few apples were borne in 1879 . Both were dead in $188_{4}$. 'Fruit, large, subacid, very good. Winter.

WESTERN BEAUTY.-Synonym of Beauty of the west. One tree was planted. It bore a few apples in 1878 and 1879 , and was dead in 1884 . Fruit, large, roundish, oblate, striped, rich red, subacid, very good in quality. Late autumn.

WESTERN SPY.-Two trees were planted. One died in 1885 and the other, which bore a fair crop of fruit in ISS6, was dead a year later.

WeSTFIELd SEEK-NO-FURTHER.-See Seek-no-further.

Wetherill's white sweEt.-One tree was planted. This bore a few apples in 1878 and 1879 and was dead in $188_{4}$. Fruit, medium size, yellow, sweet, very good in quality. Autumn.

White PEARMAIN,-Two trees were planted. One was dead in $188_{4}$, the other bore a few apples in 1886 , and was dead in 1887.

White RAWle's JANET.-Two trees were planted under this name. One was Red stripe and the other a fruit similar to White winter pearmain.

White Robinson.-Three trees were planted under this name and proved to be the same as Winter sweet paradise.

White sweET.-One tree was planted. This bore a fair crop in 1878 , a few apples in 1579 , and was dead in $\mathrm{I} 836$. Fruit, medium size, sweet, very good in quality.

White Winter PIPPIN.-Two trees were planted under this name. One was dead in ISS4. The other bore a few imperfect apples that year, but was in poor condition and died the next year.

WhITE'S LONG KEEPER. - Two trees were planted. One was dead in 1879 and the other died in $188_{7}$. The variety bore a fair crop in 1878 and a few apples in 1879 and I856. Fruit, medium to large, oblate, striped red, subacid, very good in quality. I.ate winter or spring.

WHITE WINTER.-One tree planted under this name proved to be Late strawberry.

White ZurdeL.-Two trees were planted. These were in excellent condition when taken out in $1895-6$. The trees bore a few apples in $1877, \mathbf{1} S_{91}$, and $1 S_{93}$, fair crops in ISS6, ISS9, and IS94, and full crops in I88S, IS9o, and I895. Fruit, large, roundish, greenish yellow, subacid, good in quality for cooking. October. Somewhat similar to Holland pippin.

Whitsey's No. I 4.-Two trees were planted. One died before 1886 . The other bore a fair crop that year and was dead in ISSS. Fruit, small, pleasant subacid. Autumn. Not valuable. 
Whitney's No. 20.-One tree was planted. It has records of bearing but two crops, 1886 and 1888 . The tree was taken out in 1889 . Fruit, small, roundish, conical, striped red, very pleasant, subacid, very good in quality. August.

WiLEY's GREENING. - Two trees were planted. These bore a few apples in 1878 and 1879 , and were dead in 1884 . Fruit, medium size, oblate, greenish, with $a^{\circ}$ blush. sour, good in quality. Winter.

Villiam.-One tree was planted. It bore a fair crop of large very good apples in 1879 , but was dead in 1886 .

William PrINCE.-Three trees were planted. These bore a fair crop in I878, $1879,1886,1889,1890$, and 1894 , full crops in $1884, I 888$, and $I 891$, and a few apples in 1892. The trees were in rather poor condition when taken out in 1894-5. Fruit, medium size, or below, oblate conic, yellowish green, striped red, pleasant subacid, good to very good in quality. July. Apt to be water-cored.

Willow (Willow twig). - Three trees were planted. One of these died before fruiting, another was dead in 1884 , and the third was nearly dead when cut out in 1879. The variety bore a few apples in 1884 , fair crops in 1878 and 1886 , and a full crop in 1879 . Fruit, medium to large, roundish, greenish, with more or less red, brisk subacid, good to very good. Late winter.

WILSON'S LARGE RED.-Three trees were planted. These bore a few apples in 1877 and all were dead in 1884 . Fruit, large, oblate conical, striped red, only good in quality.

WiLSON'S SUMMER.-One tree was planted under this name and two under the the name of Wilson's sweet. The variety bore a few apples in $1877,1878,1879,1884$, I889, I89I, and I894, and fair or full crops in I886, I888, I89o, and I895. Fruit, below medium size, oblate conic, nearly covered with red, subacid, almost sweet, good. in quality. August. Of no special value.

WiLson's sWEET.-Two trees planted under this name proved to be Wilson's summer.

WinE OF Kansas. - Two trees were planted. One died the same year and the other in 1887 . The variety bore a few apples in 1878 and I879. Fruit, large, oblate, almost sweet, very good in quality. Early winter.

IVINESAP. - Two trees were planted. One was dead in I886 and the other was in poor condition when taken out in $1892-3$. The variety bore a few apples in 1878,1879 , I889, I890, and I89I, and fair crops in I886 and I888. Fruit, small to medium, oblate conic. shaded dark red, rich subacid, very good in quality. Late winter.

WINTER GREEN.-One tree was planted. It bore a few imperfect apples in 1886 and was dead in 1888 .

Winter Peach.-Dame as Peach.

WINTER RED.-Two trees were planted. One tree died in 1887 and the other was in fair condition when taken out in $1895-6$. It bore a few apples in $1878,1879,1884$, I889, I890, and I895, and fair crops in 1886 and 1888 . Fruit, medium to large, oblate, strnped light red, mild subacid, only good in quality. Late winter.

WINTER STRAWBERRY.-Four trees were planted in two different parts of the orchard. The variety bore a few imperfect apples in 1886 . One tree lived until taken out in $1895-6$ without fruiting again.

WINTER SPICE.-Two trees were planted. These bore a few apples in 1877,1878 , I879, and I886. The trees were in poor condition when taken out in 1887. Fruit, of medium size, oblong conic, sweet, only good in quality. Winter.

WINTER SWEET.-Four trees were planted under this name. One died without fruiting, another proved to be the same as Harrison, and the other two were an unknown subacid, late fall apple, of little value.

Winter swEeT PARADise.-One tree was planted under this name and three 
under the name of White Robinson. The variety bore a few apples in $1886,1890,1891$, I894, and 1895 , and a fair crop in 1888 . The trees were all in fair condition when taken out in $1895-6$. Fruit, medium to large, round, light yellow, sweet, aromatic, good to very good in quality. Through winter. This variety does not agree with Downing's or Thomas's descriptions, but does agree with Warder's description under the name Paradise winter sweet.

WINTHRoP GREENING.-Two trees were planted. These bore a few apples in $1878,1889,1891,1894$, and fair crops in $1879,1886,1888$. One tree was blown down in 1859 and the other was in fair condition when taken out in $1895-6$. Fruit, medium size, oblate, greenish yellow, subacid, almost sweet, rich, very good in quality. September.

WOOD'S SWEET.-One tree planted under this name proved to be a small apple, but answered fairly to the description of Wood's sweet in other ways. It bore a few apples in 1878,1879 , and 1891 , a fair crop in 1886 , and a full crop in 1888 . The tree was taken out in $1892-3$.

Wright's JANET.-Same as Bastard Fanet. (See page 313.)

YATES.-Three trees were planted. One was dead in 1884 , another in 1886 , and the third was cut out in $1894-5$. The variety bore a few apples in 1878,1879 , and 1893 , and good or fair crops in 1877,1886 , and 1888 . Fruit, small, oblate, conic, nearly covered red, flesh colored red, subacid, pleasant, of very good quality. Through winter until May.

YeLlOW CRAB.-One tree was planted. It bore a few apples in 1878 and 1879 , and was dead in 1886 .

YELLOW JUNE.-Five trees were planted under this name and at least two varieties fruited. One was a large oblate apple, shaded red, in season in September and October, and the other was Early. harvest.

YELLOW MAY.-Synonym of Funeating. Three trees were planted under this name and another under the name of Rare ripe. The first three soon died without fruiting. The last bore several fair to good crops, beginning with I888, and died in $1893-4$. Fruit, small, roundish, pale yellow, subacid, only good in quality. First of July.

ZAWSEN VON WELTER.-One tree was planted. It bore a few apples in 1884 and I886, and was dead in 1888 . Fruit, small, roundish, subacid, striped red, only good in quality. Winter.

Some trees died before they fruited. A list of these is given so that the reader may get a more accurate idea of the extent of the planting than he would from the foregoing descriptions alone. Also some eighty so-called varieties were planted which did not prove true and were not determined.

TREeS PLANTED WHICH DID NoT LIVE TO BEAR FRUIT.

Adams, Alabama pippin, Allen's pippin, Allen's sweet, Alphian, Amelia, American marigold, American summer pippin, Andrews' red, Ananas reinette, Aucubifolia crab. Austin sweet, Autumn bongh, Autumn sweet bough, Averill. Baccolinus, Baker, Bals. burg, Baltimore, Beanty of Kent, Beauty of the West. Belle des jardens, Benjamite, Berry, Best, Bevan's favorite, Bidet, Blackburn, Black Detroit, Black crab, Black gilliflower, Black hawk, Black Annette, Black warrior, Blanche precoce, Bledsoe, Bledsoe pippin, Boran's winter, Brabant bellfower, Brennaman, Brewer, Brittle sweet, Brooks's pippin, Bruce's summer, Burnan's sweet, Burronghs' greening, Burr's winter, Bush, Butler of Indiana, Cache, Canada reinette, Cannon pearmain, Carolina red streak, Caro. line (of N. J.), Carpenter's winter, Cathead (of Penn.). Cathead (of Jones), Cedar Falls, Challenge. Champagne crab, Chace's seedling, Chester Spitzenberg, Cherokee red, Chestood, 
Coe's golden drop, Compte d'Orloff, Compton, Congress, Cook, Cook's red, Cooper's eurly white, Cornell's fancy, Cox's orange pippin, Cranberry pippin, Crane's spice, Cruwford's keeper, Crimson pippin, Crow's nest, Curtis's sweet, Dahlongea, Dodd's apple, Dodd's favorite, Donahue's late hlossom, Donahue's seedling, Dpicen sweet, Early German, Early red, Eggermont's Calville, Emperor, English crab, English golden pippin, Enslish red streak, Epting's red, Equinetely, Evening party, Ewalt, Excel, Exquisite, Fall beauty. Fall pearmain, Fall wine, Father Abraham, Favorite, Fenovillet de la Cline, Ferdinand, Fine juicy red, Fine early, Firm Walter, Flora, Flower of Kent, Foxley crab, French apple, Fulton's summer, Garrettson's early, Gelbe gestreift, Genesee chief. Gestreifter sommer apfel, Gorden's seedling, Goudie, Grab, Grafton sweet, Green bellflower, Green crank, Green Mountain russet, Green pippin, Green sweet (of Penn.), Hague, Hain, Hall, Harris, Hart's pippin, Have apple, Hocket's sweet, Holdfast, Holland pippin, Hoover, Hoover's Fune, Horse yellow, House apple, Howard's Edgemont, Howe's russet, Imperial pearmain, Indian, Indiana winter, Fohn Carter, Keim, Kennedy red, Kentucky king, Kentucky long stem, Kentucky queen, Kitita, King, King apple, King russet, Knowle's early, Krauser, Kyle's winter, La Fayette, Lake, Lancaster Co., Large May, Late pippin, Lawver, Lincoln, Locust grove, Long Island russet, Long stem sweet, Lowrie's, Ludwig, Lyon's pippin, McDonald's red, Maiden's bosom, Mann, Marks, Marston's red winter, Massay's seedling, Masten's seedling, Mattock's summer, Mattamusket, Mead's keeper, Medium red long keeper, Meigs, Merwin, Michael's sweet, Missouri pearmain, Missouri superior, Moulton's winter, Naig's August, Needles, Neversink, Norfolk beanfin, N.C. Baldwin, Nouvelles imperial, Nursery Oconee greening, Osborne's cheese, Panden sweet, Parker, Park's spice, Parrot reinette, Partnership, Passe Zettres, Pearmain russet, Pepin d'or de larg, Perkins, Perkins's winter, Pippin of Mosely, Pittsburg, Pioneer, Platte a groose queue, Poland winter, Pommaria greening, Pomme de lettres, Pound Georgia, Pound's Fuly, President, Pride of Richmond, Prior's red, Private, Ragan's red sweet, Rebecca, Red cathead, Red and green sweet, Red juneating, Red May, Red pippin (of Md.), Red sweet, Reinette, Reinette d'Anjou, Reinette de Bretange, Reinette de Canterbury, Reinette Franche, Reinette de Versailles, Reinette Doré, Reinette grise Fransaise, Reinette onze, Richmond sweet, Rich spicy, Ridge pippin, Riviere, Roadstown pippin, Robertson's red, Robertson's superb, Robey's seedling, Rock, Rock sweet, Rnsea, Royal russet, Russeting, September, Shaker, Sharpe's greening, Shiloh pippin, Shepley's, Shippen, Shippen's russet, Sine qua non, Sink, Smokey twig, Somerset, Southern Pennock, Southern winter king, Southern queen, Spitzenberg, Stanard, Strawn's seedling, Sugarloaf pippin, Summer Fanet, Summerout, Summer rose, Summer sweet paradise, Sweet Fune, Sweet meat, Syoset, Tillaqua, Transparent de Rouen crab (synonym of Rouen transparent), Turney's greening, Uncle Fohn, Unique, Vestal, Virginia cathead, Wagener, Wall, Walpole, Washington sweet, Watauga, Waugh's crab, Weidner's golden reinette, West's Spitzenberg, Wiley's sweet, Willow leaf, Winslow, Winter buff, Winter cheese (of Ky.), Winter Harvey, Winter red streak, Wood's winter, Wonder, Yacht, Yahoola, Yellow bough, Yellow Newton pippin, York imperial.

\section{T. J. Burrill, Ph. D., Horticulturist. G. W. McCluek, M. S., Assistant Horticulturist.}







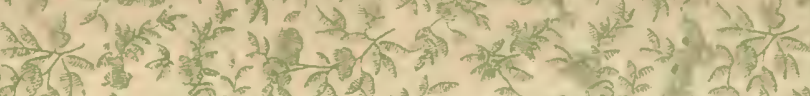

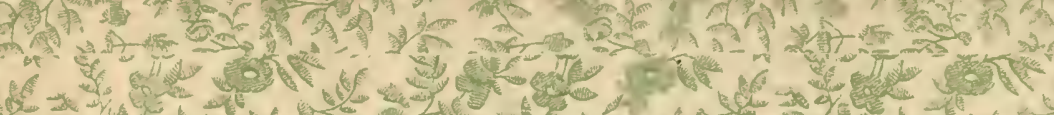
L2. a

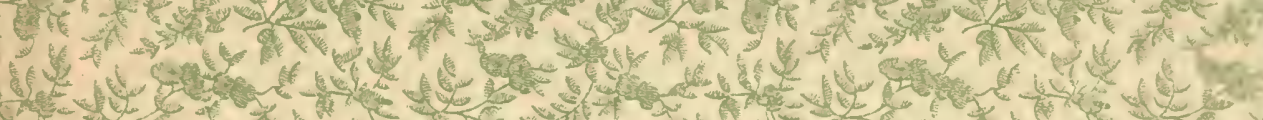
A.

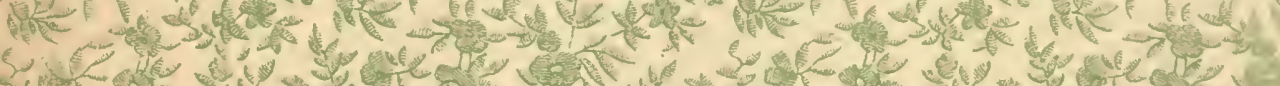
से

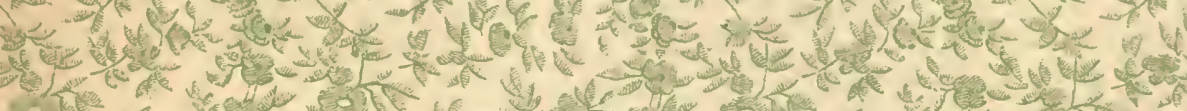

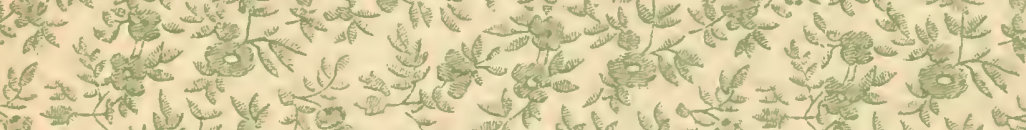
(5)

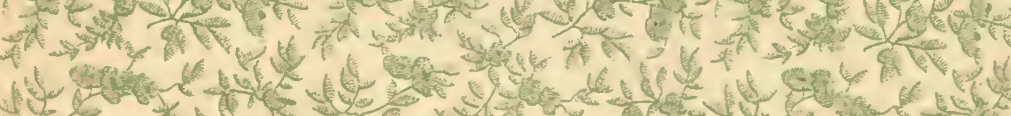

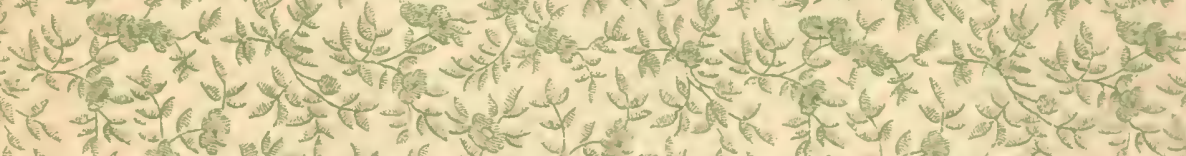
s.

$$
\text { (1) }
$$

10 की
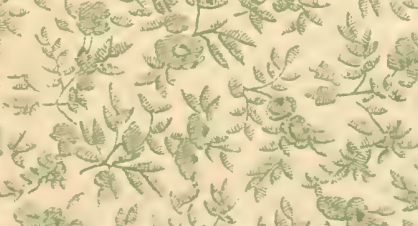

-

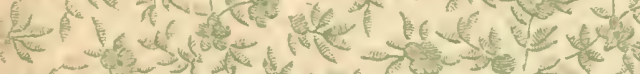

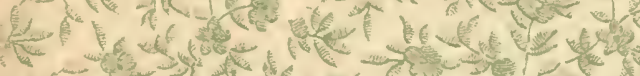
in

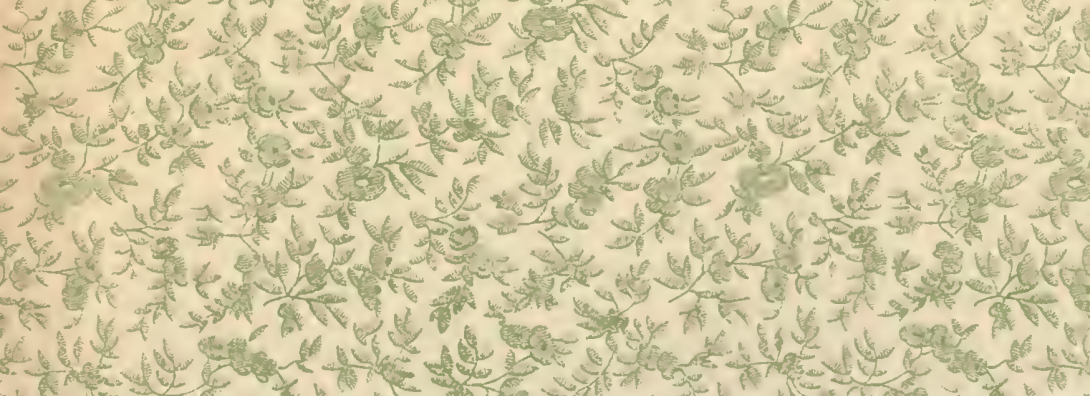

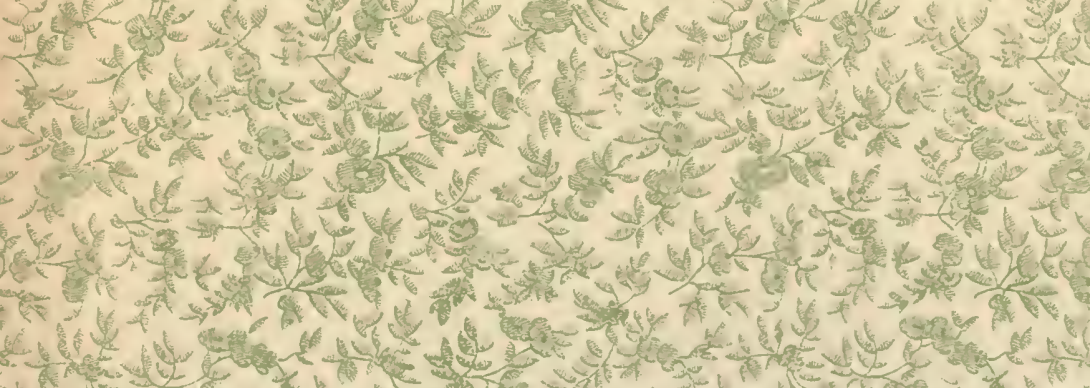

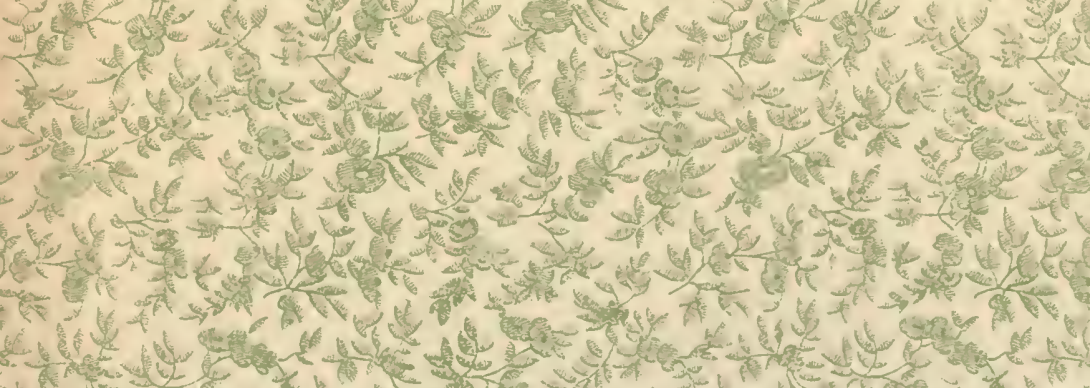

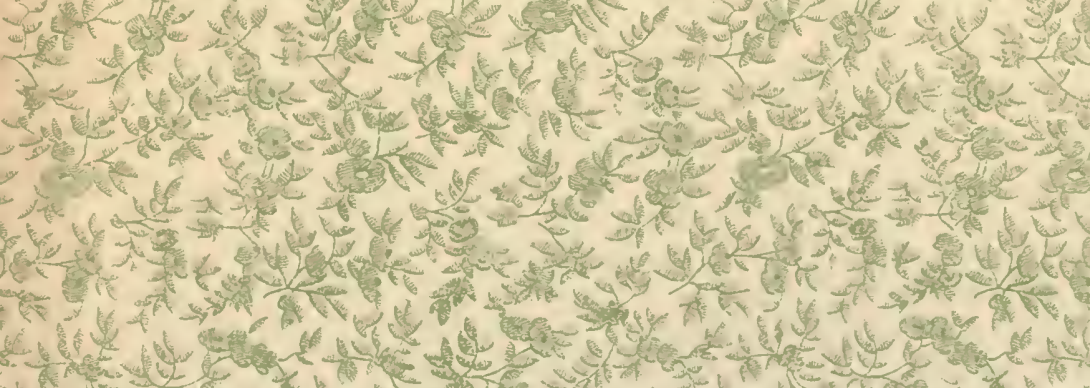

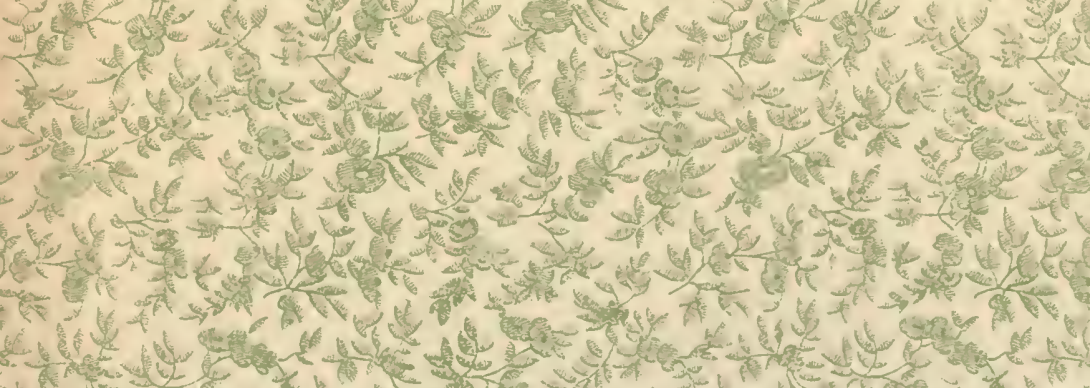

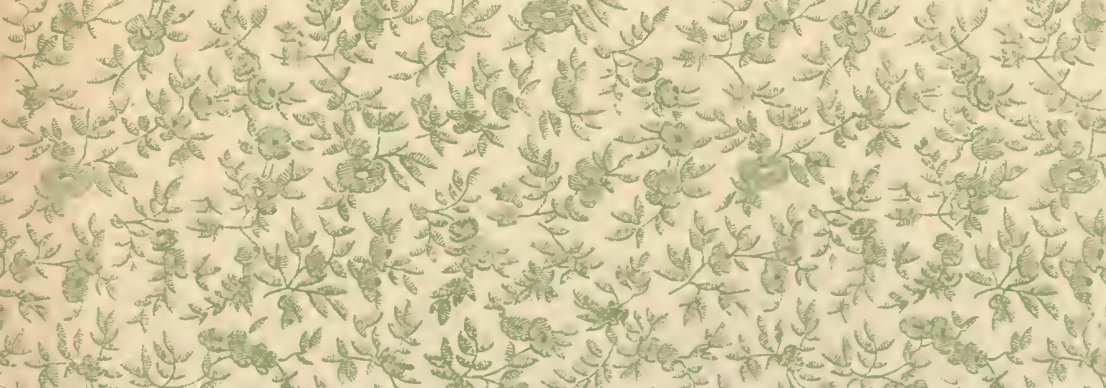

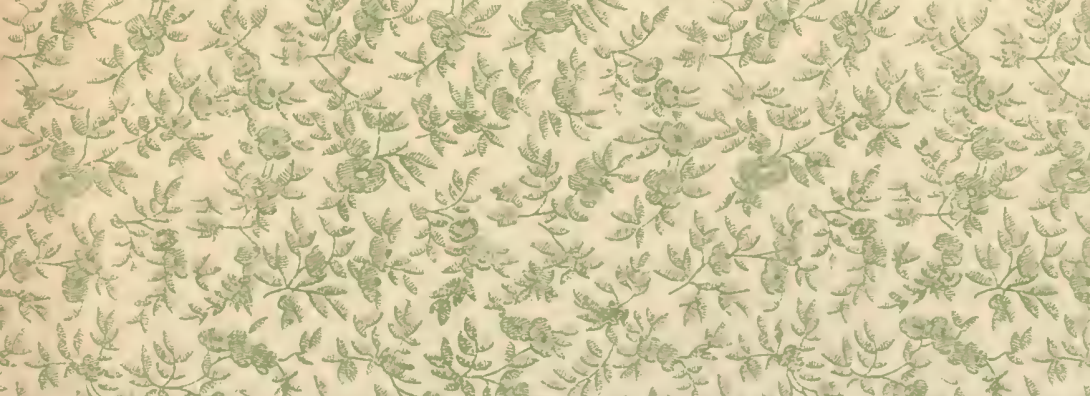
5 (1)

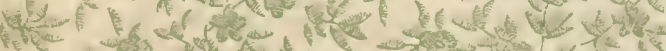


A

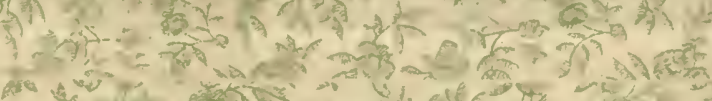

(2) (1) 1. 50 t

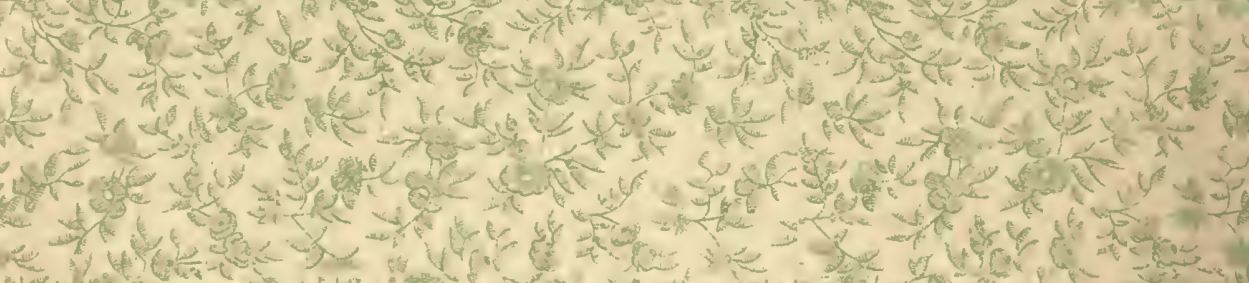

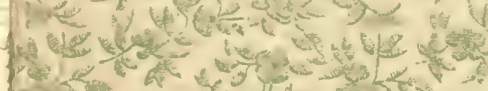

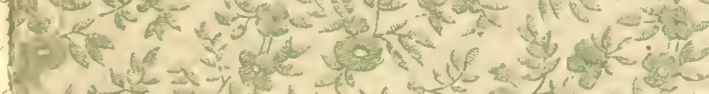

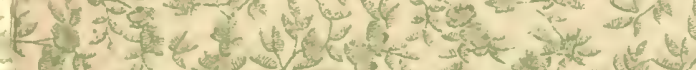

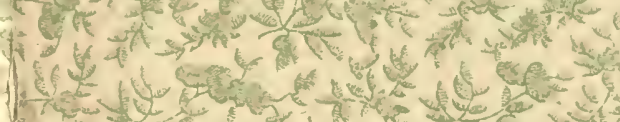

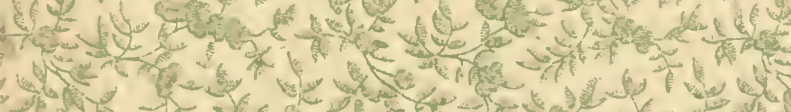

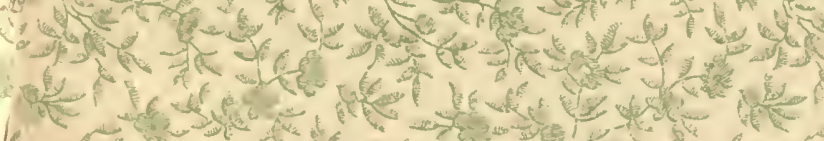

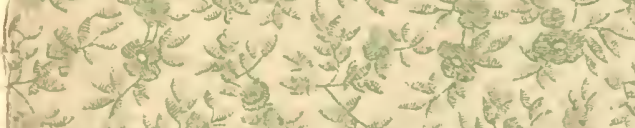

1. (2) 
UNIVERSITY OF ILLINOIS-URBANA

a. 630.71 L6B

BULLETIN. URBANA

C001

37-48 1895-97

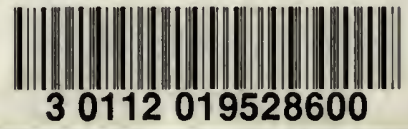

